\title{
Quantitative mapping of active mud volcanism at the western Mediterranean Ridge-backstop contact
}

\author{
Alain Rabaute · Nicolas Chamot-Rooke
}

Received: 30 January 2007 / Accepted: 23 July 2007 / Published online: 6 September 2007

(C) Springer Science+Business Media B.V. 2007

\begin{abstract}
Based on a new quantitative analysis of sidescan sonar data combined with coring, we propose a revised model for the origin for Mediterranean Ridge mud volcanism. Image analysis techniques are used to produce a synthetic and objective map of recent mud flows covering a $640 \times 700 \mathrm{~km}^{2}$ area, which represents more than half of the entire Mediterranean Ridge mud belt. We identify 215 mud flows, extruded during the last 37,000-60,000 years. This time period corresponds to the limit of penetration of the sonar, that we evaluate through geoacoustic modeling of the backscattered signal returned by the mud brecciahemipelagites contact, and calibrate by coring. We show that during this period, at least $96 \%$ of the mud volume has been extruded at the Mediterranean Ridge-Hellenic backstop contact, the remaining being scattered over the prism. We suggest that the source is a Messinian (5-6 Ma) mud reservoir that remained close to the backstop contact, at variance with the classical transport-through-the-wedge model. A revised mud budget indicates that steady-state input is not needed. We propose that the source layer was deposited in deep and narrow pre-Messinian basins, sealed by Messinian evaporites, and finally inverted in postMessinian times. Onset of motion of the Anatolia-Aegea microplate in the Pliocene resulted in change from slow to fast convergence, triggering shear partitioning at the edges of the backstop and basin inversion. Mud volcanism initiation is probably coeval with the latest events of this kinematic re-organization, i.e. opening of the Corinth Gulf and activation of the Kephalonia fault around 1-2 Ma.
\end{abstract}

A. Rabaute $(\bowtie) \cdot$ N. Chamot-Rooke

Laboratoire de Géologie, Ecole normale supérieure, CNRS UMR

8538, 24, Rue Lhomond, Paris Cedex 05 75231, France

e-mail: rabaute@geologie.ens.fr
Keywords Mediterranean Ridge - Mud volcanism . Acoustic characterization - Backscatter - Geodynamics . Messinian evaporites $\cdot$ Accretionary prism $\cdot$ Backstop · Strike-slip faults

\section{Introduction}

Mud volcanoes have been found in various geological contexts in the Mediterranean seas, including Tertiary and Mesozoic basins (Alboran Sea, Black Sea, Levantine Basin, see Pérez Belzuz et al. (1997), Ivanov et al. (1996b), Netzeband et al. (2006)), Neogene accretionary prisms (Mediterranean Ridge; Calabrian Prism, see Ceramicola et al. (2006); Gulf of Cadiz, see Van Rensbergen et al. (2005) and Hensen et al. (2007)), and sedimentary cones (Nile, see Loncke et al. (2004)). In the Eastern Mediterranean, mud volcanism is present as one more or less continuous belt along the Mediterranean Ridge referred to as the Mediterranean Ridge mud diapiric belt (Limonov et al. 1996). As in other marine accretionary environments associated with mud volcanism, and in particular the Barbados prism, the Mediterranean Ridge mud fields have been related to dewatering of the Mediterranean sediments incorporated into the prism in the context of subduction of the African plate beneath the Anatolia plate.

In many accretionary complexes, mud volcanoes are found close to the frontal thrust-generally within the first tens of kms of prism - and in several cases seaward of it. At the eastern end of the Java Trench, mud volcanoes and mud ridges parallel the thrust front, some $10-15 \mathrm{~km}$ ahead of it (Breen et al. 1986). Mud volcanoes are reported in the same region ahead of the Flores thrust (Silver et al. 1986) and Wetar thrust (Breen et al. 1989). Mud mounds are also described in the proto-thrust zone 
of the eastern Nankai thrust (Kobayashi et al. 1992). Mud ridges and domes were discovered immediately off the Burma front in the Bengal plain (Nielsen et al. 2004), as well as within the prism, in a subduction context. The best studied example so far is the Barbados accretionary prism (Brown and Westbrook 1988; Henry et al. 1990; Le Pichon et al. 1990; Sumner and Westbrook 2001). There, exhaustive surveys indicate that mud volcanoes are found evenly scattered in the outer portion of the prism (Brown and Westbrook 1988).

In contrast with the Barbados accretionary complex, mud volcanism of the Mediterranean Ridge is not uniformly distributed, but concentrates into an inner belt at the prism-backstop contact (Camerlenghi et al. 1995; Huguen et al. 2004). This paper addresses the distribution of mud volcanism with respect to the main geological contacts (frontal thrust, wedge-backstop backthrust), by use of multibeam and acoustic data covering the western and central Mediterranean Ridge. Image analysis techniques are used to automatically extract mud flows from reflectivity images. The results are validated with available cored material. We present a map of the mud volcanism that covers an area of $600 \times 740 \mathrm{~km}$, and discuss it in terms of mud volcanoes distribution within different parts of the prism. We estimate that $96 \%$ of the mud volume is expelled in the so-called inner belt, the outer belt playing a marginal role in the overall mud budget. We propose an alternative to the dewatering wedge model that we call the "reservoir model". In this model, the source for mud volcanism is assumed to be mud deposited close to the wedge-backstop contact in deep pre-Messinian forearc basins, which were later inverted. We test this new scenario against recent tectonics of the Hellenic arc and Aegean domain.

\section{Mud volcanism over the western Mediterranean Ridge}

Over the last 10 years, the eastern branch of the Mediterranean Ridge has been heavily surveyed and sampled using side-scan sonar, seismics, submersible, coring, dredging, and in-situ fluids sampling, with a focus on several important mud fields: Olimpi, United Nations, Strabo, Anaximander, Florence Rise, Nile cone (see Fig. 1, labels $\mathrm{f}-\mathrm{k}$ ). The morphology of the mud volcanoes, their possible control by tectonic features and the mechanisms of extrusion were described (see recent works by Huguen (2001); Huguen et al. (2004); Zitter (2004); Zitter et al. (2005); Huguen et al. $(2005,2006))$.

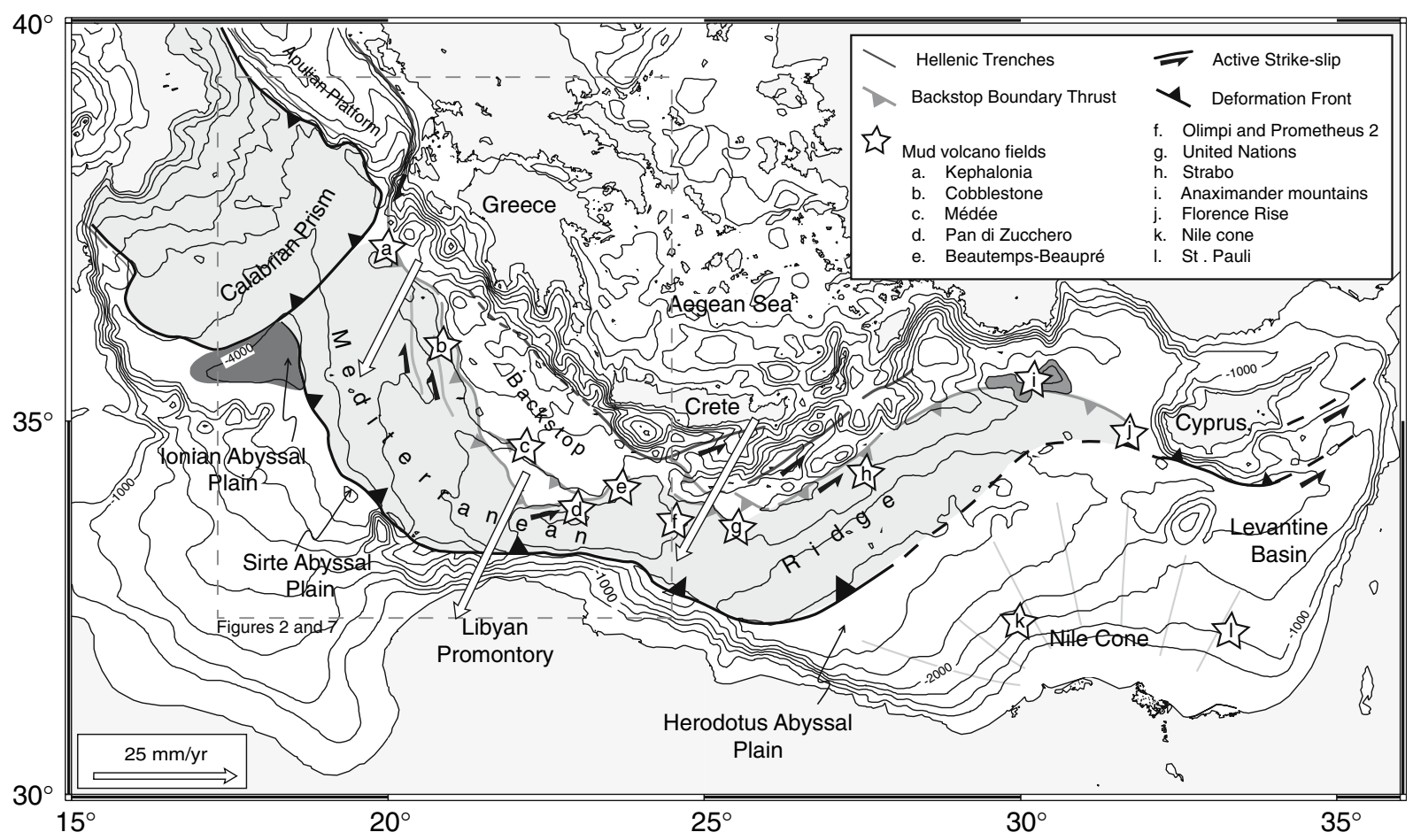

Fig. 1 Geological setting of the Eastern Mediterranean, showing the Mediterranean Ridge in contact with the Aegean backstop. The empty stars figure the surveyed mud volcano fields, (a) Kephalonia, (b) Cobblestone, (c) Pan di Zucchero, (d) Olimpi and Prometheus 2, (e)
United Nations, (f) Strabo, (g) Anaximander Mountains, (h) Nile Cone, (i) St Pauli. Motion of the backstop with respect to Africa is taken from Kreemer and Chamot-Rooke (2004). Dashed frame figures the extent of Figs. 2 and 7 
On the other hand, mud fields in the western part of the Mediterranean Ridge (west of $24^{\circ} \mathrm{E}$ ) remain poorly known. Two areas were surveyed and cored in this western portion, mainly by Italian teams:

(1) The Cobblestone area was discovered and investigated during several cruises between 1978 and 1988 (Cita et al. 1981; Ryan et al. 1982; Cita et al. 1982). It is located southwest of the Peloponnesus, close to the crest of the Mediterranean Ridge in the Ionian Sea (Fig. 1, western branch of the Mediterranean Ridge, label b). Mud volcanism was confirmed by coring and sonar images (Cita et al. 1981; Ryan et al. 1982; Limonov et al. 1995).

2) The Pan di Zucchero area is located half-way between Crete and Libya (Fig. 1, central branch of the Mediterranean Ridge, label d), in a broad area that has been mapped as the highest point of the Mediterranean Ridge (Camerlenghi et al. 1992, 1995; Hieke et al. 1996). The very top of the Mediterranean Ridge is an elevation observed west of the Pan di Zucchero 2, and called Antaeus high (Hieke et al. 1996). Coring and seismic surveys (Camerlenghi et al. 1992, 1995; Staffini et al. 1993; Fusi and Kenyon 1996; Hieke et al. 1996) suggested that the elongated domes that form the top of the Mediterranean Ridge are actually mud diapirs, rather than mud volcanoes.

Three new mud fields were identified and named in the course of this study: the Kephalonia area (Fig. 1, western branch of the Mediterranean Ridge, label a), the Médée area (Fig. 1, western branch of the Mediterranean Ridge, label c), and the Beautemps-Beaupré area (Fig. 1, central branch of the Mediterranean Ridge, label e). The extension of the latter was completed during the SIMED-MEDOR cruise in 2004 (Huguen et al. 2006, not included in this study).

We focus on a large area of $600 \times 740 \mathrm{~km}$ based on the MEDEE marine survey of the $R / V$ l'Atalante in the Eastern Mediterranean. The swath mapping using the Simrad EM12-D multibeam echo-sounder (operated at $12-13 \mathrm{kHz}$ ) provided a set of detailed bathymetric maps contoured at an interval of $20 \mathrm{~m}$, and reflectivity images showing the strength of the sea-floor backscattering of the side-scan sonar signal. The survey includes the five mud fields identified in the Mediterranean Ridge west of $24^{\circ} \mathrm{E}$, namely Kephalonia, Cobblestone, Médée, Pan di Zucchero and Beautemps-Beaupré areas, and was divided into 19 maps at a scale of 1:150,000 (Fig. 2a). Each of them was analysed in terms of high backscattered intensity patches, known to indicate fresh mud flows. Marine mammals are suspected to find these acoustic bright spots by echolocation and to feed themselves on the abundant associated benthic fauna (Woodside et al. 2006). The maps were cut so they overlap each other on their four sides. Finally, we used the overlapping to check the coherence of the results of the image analysis between two or more neighbour maps.

\section{Characteristic features extraction from multibeam data and reflectivity images}

Figure $2 b$ shows an image of the acoustic reflectivity recorded over the Mediterranean Ridge during the MEDEE cruise. Striking features include the lower backscatter intensity of the backstop with respect to that of the Mediterranean Ridge, and the unevenly scattered patches of very high reflectivity that concentrate at the prism-backstop boundary. This very strong acoustic backscattering signature and the moundshape morphology are two major characteristics of a mud volcano that we briefly summarize below.

Backscattering of an acoustic wave on a layer of sediment is the result of two contributions (Hamilton 1980; Jackson et al. 1986): (1) a surface backscattering at the interface between water and sediments, and (2) a volume backscattering, both strongly correlated to the presence of heterogeneities (e.g. clasts, gas inclusions, carbonate crusts). The high backscatter intensity on the sea floor seems to be closely related to the nature of the erupted material (Cita et al. 1981; Staffini et al. 1993; Zitter et al. 2005). The mud breccia contain clasts and gas which form the volume scatterers of the acoustic signal (Volgin and Woodside, 1996). A thorough review of the possible causes of high backscatter can be found in Zitter et al (2005).

The morphology of a typical mud volcano is characterized by a more or less mounded topography, with a top culminating between $50 \mathrm{~m}$ and $200 \mathrm{~m}$ above the regional sea-floor level (Cita et al. 1981; Ryan et al. 1982; Camerlenghi et al. 1992). Almost all of the mud volcanoes investigated and checked in the Mediterranean Ridge have shown gentle slopes, ranging between $5^{\circ}$ and $10^{\circ}$ (Camerlenghi et al. 1992; Hieke et al. 1996; GalindoZaldivar et al. 1996). An exception is the Napoli mud volcano in the Olimpi mud volcano field, which shows unusual step-like flanks, with slopes up to $16^{\circ}$. Another characteristic feature of most mud volcanoes is the collapse ring structure around the principal eruption conduit (Ivanov et al. 1996b). This rim syncline around the mud dome was considered to be the result of salt dissolution (Hieke et al. 1996). Other authors consider this explanation as less likely (Galindo-Zaldivar et al. 1996) as there is no systematic evidence for salt dissolution (for example depressions along fault systems, or around smaller mud volcanoes), and there is ample evidence of collapse structure around mud volcanoes in areas where salt is not present in the upper sedimentary section (for example in the Black Sea). These authors suggest that the ring depressions are probably a 


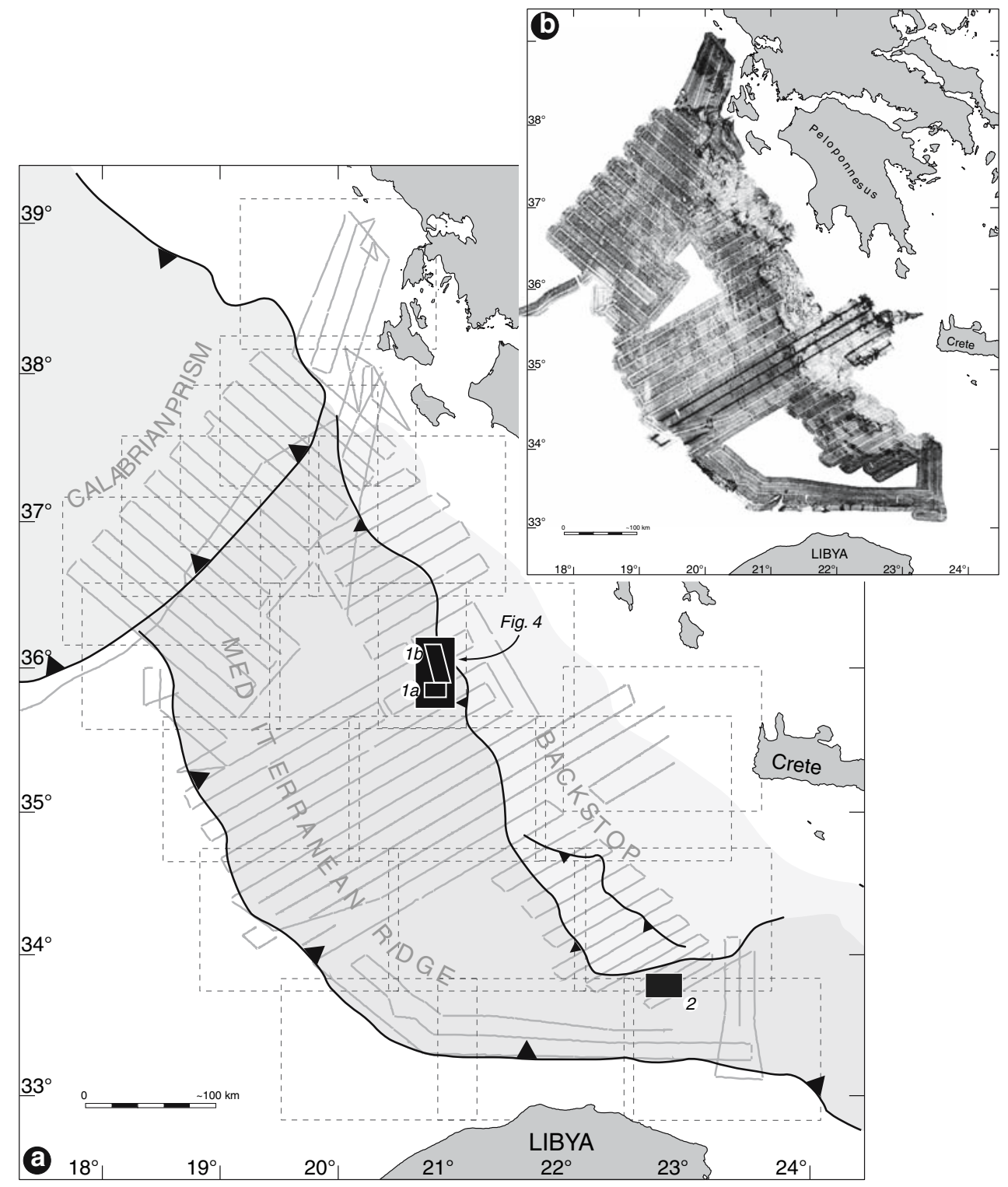

Fig. 2 (a) General setting of the MedeE area, together with the vessel tracklines during acquisition, and the (1) 150,000 scale boxes (dashed contours). (1a and b) Cobblestone area; (2) Pan di Zucchero area. (b) Reflectivity map of the survey area

consequence of the load of the volcano on poorly consolidated sediments.

We analysed the reflectivity images using a two-stage procedure. The first step is an automated analysis of the seafloor acoustic reflectivity. Figure 3 shows a schematic flow chart of the reflectivity image typical analysis. An example of a reflectivity image is given (Fig. 3a). The image analysis procedure is detailed in Appendix A. The result of the processing is two twin images representing the medium (Fig. 3c) and high reflectivity (Fig. 3d).

The second step of our analysis is the identification of mud flows and the removal of artefacts. We particularly consider tectonic and geomorphologic effects, such as land slides on steep slopes, coarse-grained filled basins, or the crest of active folds, as they can also result in high backscatter intensity. Both reflectivity maps are used with the bathymetry, the morpho-structural interpretation (ChamotRooke et al. 2005b) and core information where available, to produce a map (Fig. 3e), that can be superimposed on bathymetry and structures (Fig. 4). In the course of this morphologic analysis, we observed that each flow is almost systematically associated with mounded relief. A detailed inspection of morpho-bathymetry indicates very few mounded structures that are not associated with high reflectivity patches. These could possibly be buried and thus undetected mud volcanoes. 

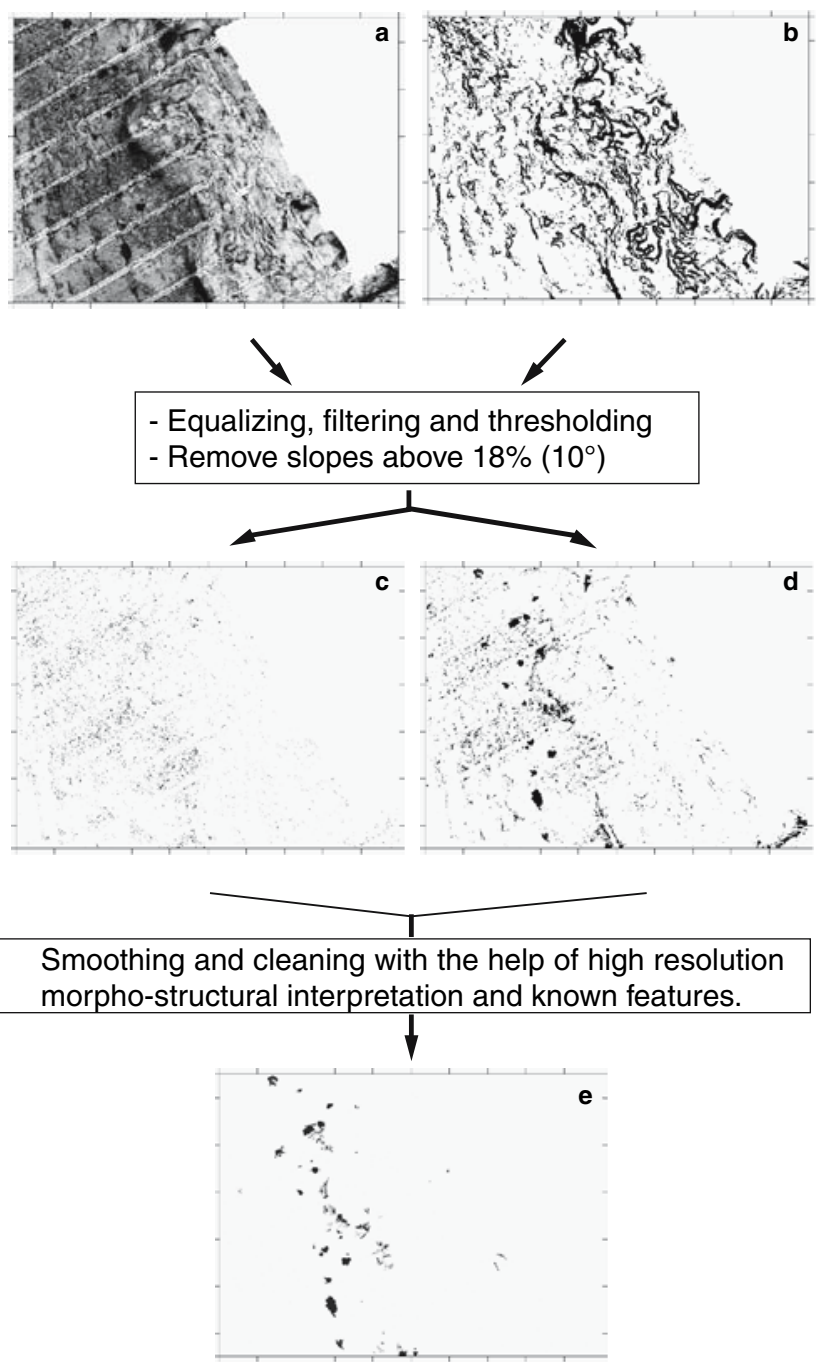

Fig. 3 Schematic flow chart of the reflectivity image analysis

\section{Correlation between cored material and reflectivity}

Figure 4 shows the Cobblestone area, with the two specific areas surveyed between 1978 and 1995. We show the location and numbers of the piston and gravity cores and the named mud volcanoes. The characteristics of the cores recovered in the Cobblestone and Pan di Zucchero areas are given in Table 1. All the mud volcanoes checked by core analysis (Cores 24, 25E, 28 and 38, and Cores 160G, $162 \mathrm{G}$ and $164 \mathrm{G}$ ) have been properly inferred from image analysis (Aros, Novorossiysk, Prometheus Dome and Unnamed mud volcanoes).

Figure 5 shows a detailed view of Areas 1a and b, together with their original seafloor acoustic reflectivity, and the location of the piston and gravity cores. In Area 1a, the shape of the inferred mud flow from the Prometheus Dome corresponds particularly well with the extension of the mud breccia, as found by the tight coverage of the piston coring. The northern part of this mud flow ends abruptly, as we see that Core 31 , which is $11.25 \mathrm{~m}$-long and located at the rim of the mud flow, does not show any occurrence of mud breccia. Core 21 is reported to have recovered only mud breccia, but on the outside of the core barrel (Cita et al. 1982). We do not see any reflectivity associated with it. Furthermore, Core 20, located about $400 \mathrm{~m}$ east of Core 21 , and $4.6 \mathrm{~m}$ long, does not show any occurrence of mud breccia nor any reflectivity. It is then likely, as stated by Cita et al. (1982), that the mud breccia subsurface contact is too deep (ca. $2 \mathrm{~m}$ below seafloor, mbsf) to induce any significant reflectivity.

In Area $1 \mathrm{~b}$ of the Cobblestone area, mud breccia was found in Cores 160G, 162G and 164G (Limonov et al. 1995). Core $164 \mathrm{G}$ is located near the top of the Novorossiysk mud volcano. The detected reflectivity patch (Fig. 5-R1b) is very homogeneous, intense and roundshaped, as found previously (Limonov et al. 1995). North of Novorossiysk, a structure was identified as a possible buried mud volcano although one core $(163 \mathrm{G})$ taken near its foothills does not show any occurrence of mud breccia. We indeed observed two mud flows, flowing away from the core location, and which seem to come from the nearby rounded structure (open star, Fig. 5). The medium reflectivity characterizing these mud flows indicates a deeper burial of the mud flows, and thus confirms its past activity. Core $162 \mathrm{G}$ corresponds to Aros mud volcano. The corresponding mud flow was not detected completely due to the vessel blind path during acquisition crossing right on top of the dome structure. The possible buried mud volcano identified northwest of Aros (Limonov et al. 1995) corresponds in Fig. 5 to the rounded structure sampled by Core $161 \mathrm{G}$, although no mud breccia was recovered in this core. A recent mud flow can be identified flowing southeast of the inferred emission point (open star). Core 160G recovered mud breccia although no reflectivity is associated with it. Due to the local steep seafloor slope, the reflectivity was entirely removed during image analysis. However, a nearby rounded feature, located immediately south of Core $160 \mathrm{G}$, and surrounded by patches of medium to high reflectivity, could correspond to the mud volcano.

Figure 6 shows the Pan di Zucchero area, together with the location of the piston cores. As stated by Hieke et al. (1996), the elevations named Pan di Zucchero and Pan di Zucchero 2 do not appear to be mud volcanoes, because they do not show any high or medium reflectivity. However, a large area of medium to high reflectivity covers and surrounds the Antaeus high, which we infer to be a mud volcano. We also interpret as a mud flow the high reflectivity area south of Scarpata Vertiginiosa. We locate the inferred emission point of the corresponding mud volcano on the circular feature southwest of Core 19 (open star). Two of the eight cores collected in this area recovered mud breccia, namely Cores 20 and 2, with a mud breccia contact 


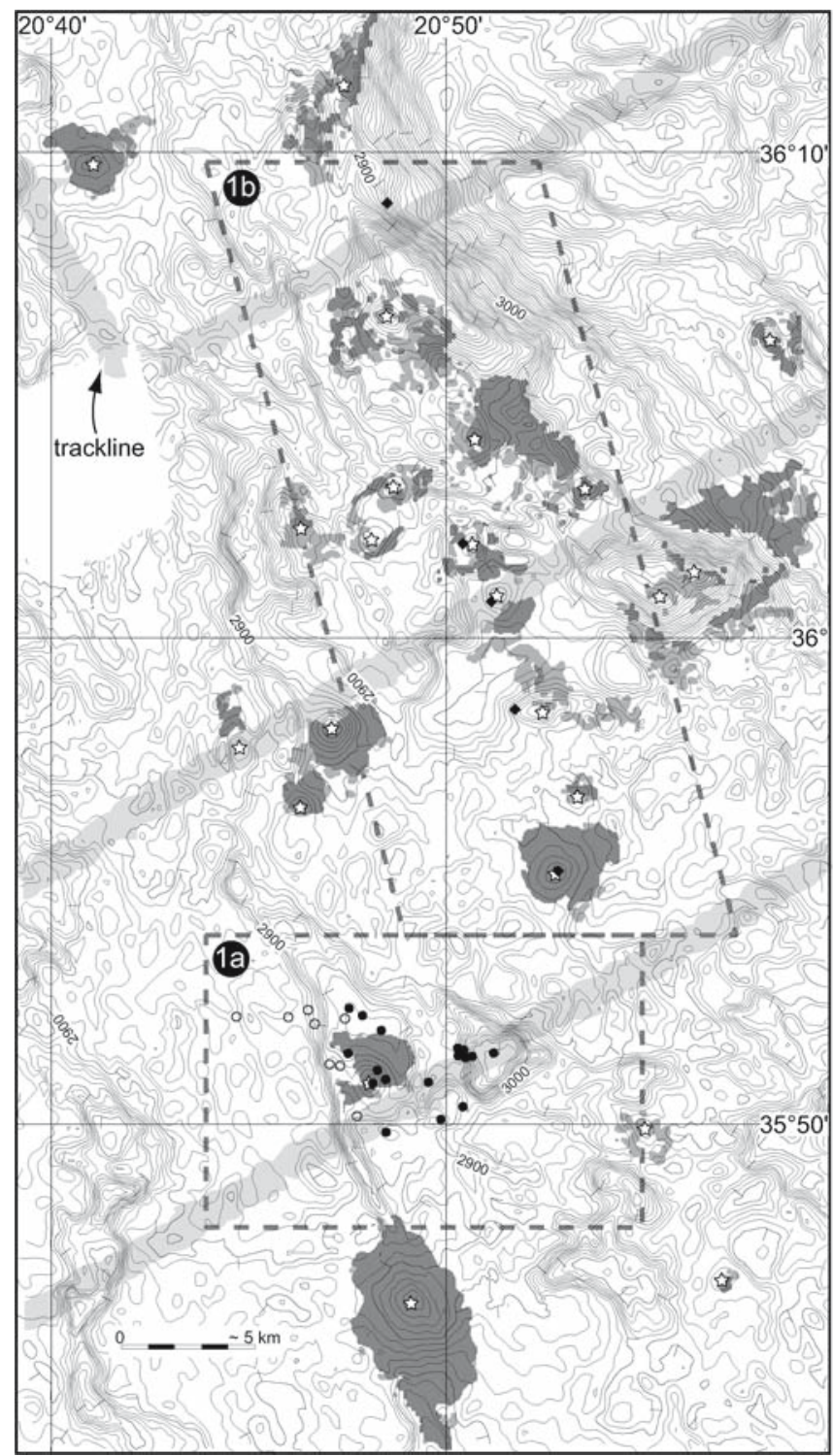

Fig. 4 Detected mud flows and inferred emission points in the Cobblestone Area. (1a) Area surveyed during $R / V$ Eastward ' 78 (cores: filled circles; (Cita et al. 1981)) and $R / V$ Bannock ' 81 (cores: empty circles; (Cita et al. 1982)) cruises; (1b) Area surveyed during $R / V$ Gelendzhik '94 (cores: filled diamonds; (Limonov et al. 1995)) cruise. Empty star: inferred emission point (the circle centered on it figures

occurring at 0.53 and $4.2 \mathrm{~m}$ below the sea floor, respectively. Core 2 is located in Castiglione Basin, at the rim of the inferred mud flow coming from a nearby local high (open star). The mud breccia found in this core may be related to an older, and thus deeper buried, mud flow. Core 20 is located in an intermediate plateau between the Pan di Zucchero high and the Castiglione Basin. The very small patch of high reflectivity associated with this core could not be associated to a closeby rounded structure nor to the patches of high reflectivity visible nearby (south and southeast of the core), and was therefore removed. A

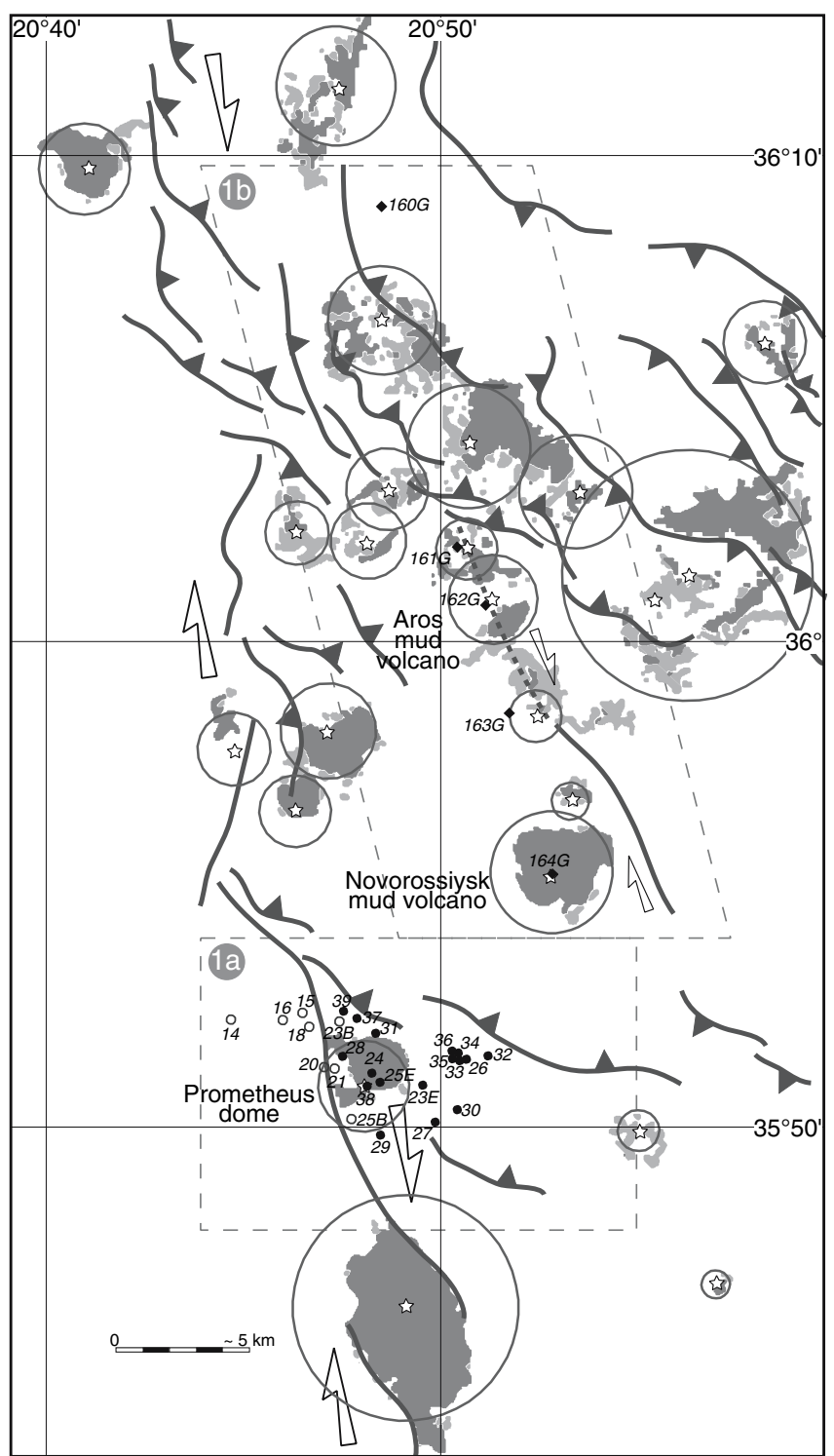

roughly the relative importance of the mud dome). Mud flows: High reflectivity (dark grey) and medium reflectivity (medium grey) are shown. Light grey strips across the figure represent roughly the extension of the specular reflection (blind path) during data acquisition. Bathymetric contours every $20 \mathrm{~m}$. On the right is shown the structural interpretation based on morpho-bathymetry and available seismic profiles

general observation about the Pan di Zucchero area is its higher background reflectivity with respect to Cobblestone area (compare Figs. 6-R2 with 5-R1a and R1b).

\section{Mud volcanoes statistics and volumetric budget}

Size

Figure 7 shows the location and importance of mud volcanism in the entire survey area. We individualize $215 \mathrm{mud}$ flows (Table 2) summing up to a total of $1474.3 \mathrm{~km}^{2}$ of 
Table 1 Characteristics of the cores recovered in Cobblestone and Pan di Zucchero areas, with corresponding main references

\begin{tabular}{|c|c|c|c|c|c|c|c|c|c|}
\hline \# & Lon & Lat & $\mathrm{MBC}$ & TCL & GL & Dev & RI & GA & RL \\
\hline \multicolumn{10}{|c|}{ Bannock '81 (R/V Bannock), Cobblestone area (Cita et al. 1981, 1982) } \\
\hline 21 & $20^{\circ} 47.43^{\prime}$ & $35^{\circ} 51.17^{\prime}$ & 2 & 3.10 & 57.0 & 3.7 & -31.4 & 53.30 & $\mathrm{~B}$ \\
\hline $23 \mathrm{~B}$ & $20^{\circ} 47.87^{\prime}$ & $35^{\circ} 52.13^{\prime}$ & 9.25 & 10.59 & 46.5 & 3.6 & -35.9 & 39.43 & B \\
\hline 18 & $20^{\circ} 46.78^{\prime}$ & $35^{\circ} 52.03^{\prime}$ & no br. & 3.80 & 60.4 & 8.8 & -29.9 & & M (slope) \\
\hline 14 & $20^{\circ} 44.80^{\prime}$ & $35^{\circ} 52.18^{\prime}$ & no br. & 0.88 & 57.0 & 6.6 & -31.4 & & B \\
\hline 15 & $20^{\circ} 46.62^{\prime}$ & $35^{\circ} 52.32^{\prime}$ & no br. & 4.32 & 54.9 & 7.8 & -32.3 & & B \\
\hline 20 & $20^{\circ} 47.15^{\prime}$ & $35^{\circ} 51.20^{\prime}$ & no $b r$. & 4.65 & 54.1 & 4.4 & -32.7 & & B \\
\hline $25 \mathrm{~B}$ & $20^{\circ} 47.87^{\prime}$ & $35^{\circ} 50.13^{\prime}$ & no br. & 0.73 & 48.9 & 8.6 & -34.9 & & $\mathrm{~B}$ \\
\hline 16 & $20^{\circ} 46.13^{\prime}$ & $35^{\circ} 52.17^{\prime}$ & no br. & 2.85 & 45.5 & 3.1 & -36.4 & & B \\
\hline \multicolumn{10}{|c|}{ Cobblestone project '78 (R/V Eastward), Cobblestone area (Ryan et al. 1982) } \\
\hline 24 & $20^{\circ} 48.37^{\prime}$ & $35^{\circ} 51.08^{\prime}$ & 0.39 & 1.30 & 75.2 & 3.7 & -23.5 & 65.03 & $\mathrm{H}$ \\
\hline $25 \mathrm{E}$ & $20^{\circ} 48.58^{\prime}$ & $35^{\circ} 50.90^{\prime}$ & $1.25^{\mathrm{a}}$ & 1.84 & 69.1 & 3.1 & -26.2 & 72.87 & $\mathrm{H}$ \\
\hline 28 & $20^{\circ} 47.63^{\prime}$ & $35^{\circ} 51.43^{\prime}$ & 0.57 & 1.32 & 73.9 & 3.3 & -24.1 & 50.62 & $\mathrm{H}$ \\
\hline 38 & $20^{\circ} 48.18^{\prime}$ & $35^{\circ} 50.80^{\prime}$ & 0.81 & 1.39 & 65.1 & 5.0 & -27.9 & 70.14 & M \\
\hline 30 & $20^{\circ} 50.53^{\prime}$ & $35^{\circ} 50.33^{\prime}$ & no br. & 9.31 & 63.8 & 4.8 & -28.5 & & M \\
\hline 27 & $20^{\circ} 49.97^{\prime}$ & $35^{\circ} 50.08^{\prime}$ & no br. & 7.07 & 56.1 & 5.7 & -31.8 & & B \\
\hline 32 & $20^{\circ} 51.30^{\prime}$ & $35^{\circ} 51.45^{\prime}$ & no br. & 11.55 & 53.6 & 6.0 & -32.9 & & $\mathrm{~B}$ \\
\hline 37 & $20^{\circ} 48.00^{\prime}$ & $35^{\circ} 52.22^{\prime}$ & no br. & 2.00 & 53.6 & 3.9 & -32.9 & & $\mathrm{~B}$ \\
\hline 26 & $20^{\circ} 50.78^{\prime}$ & $35^{\circ} 51.37^{\prime}$ & no br. & 7.76 & 52.2 & 14.2 & -33.5 & & B \\
\hline 39 & $20^{\circ} 47.67^{\prime}$ & $35^{\circ} 52.37^{\prime}$ & no br. & 1.88 & 46.5 & 5.2 & -35.9 & & $\mathrm{~B}$ \\
\hline 35 & $20^{\circ} 50.42^{\prime}$ & $35^{\circ} 51.38^{\prime}$ & no br. & 5.57 & 40.3 & 9.0 & -38.6 & & B \\
\hline 33 & $20^{\circ} 50.58^{\prime}$ & $35^{\circ} 51.35^{\prime}$ & no br. & 2.94 & 30.8 & 5.3 & -42.8 & & B \\
\hline 36 & $20^{\circ} 50.40^{\prime}$ & $35^{\circ} 51.55^{\prime}$ & no br. & 3.01 & 26.8 & 9.0 & -44.5 & & B \\
\hline 34 & $20^{\circ} 50.55^{\prime}$ & $35^{\circ} 51.52^{\prime}$ & no br. & 2.01 & 23.6 & 11.6 & -45.9 & & B \\
\hline $23 \mathrm{E}$ & $20^{\circ} 49.65^{\prime}$ & $35^{\circ} 50.83^{\prime}$ & no data & & & & & & \\
\hline 29 & $20^{\circ} 48.62^{\prime}$ & $35^{\circ} 49.80^{\prime}$ & no data & & & & & & \\
\hline 31 & $20^{\circ} 48.47^{\prime}$ & $35^{\circ} 51.90^{\prime}$ & no data & & & & & & \\
\hline \multicolumn{10}{|c|}{ Bannock '89 (R/V Bannock), Pan di Zucchero area (Hieke et al. 1996) } \\
\hline 20 & $22^{\circ} 48.40^{\prime}$ & $33^{\circ} 46.17^{\prime}$ & 0.53 & 1.95 & 64.2 & 4.8 & -28 & 53.52 & M \\
\hline 2 & $22^{\circ} 49.63^{\prime}$ & $33^{\circ} 44.82^{\prime}$ & 4.2 & 5.01 & 62.5 & 4.8 & -29 & 24.86 & M \\
\hline 19 & $22^{\circ} 48.87^{\prime}$ & $33^{\circ} 45.17^{\prime}$ & no br. & 4.61 & 66.4 & 4.9 & -27.3 & & H (slope) \\
\hline 18 & $22^{\circ} 48.68^{\prime}$ & $33^{\circ} 46.87^{\prime}$ & no br. & 5.08 & 63.5 & 9.2 & -28.6 & & M \\
\hline 15 & $22^{\circ} 48.00^{\prime}$ & $33^{\circ} 47.33^{\prime}$ & no $b r$. & 2.37 & 62.8 & 4.7 & -28.9 & & M \\
\hline 14 & $22^{\circ} 48.07^{\prime}$ & $33^{\circ} 47.33^{\prime}$ & no br. & 2.26 & 61.6 & 4.3 & -29.4 & & M \\
\hline 16 & $22^{\circ} 48.28^{\prime}$ & $33^{\circ} 46.67^{\prime}$ & no $b r$. & 0.70 & 58.2 & 6.5 & -30.9 & & M \\
\hline 17 & $22^{\circ} 48.93^{\prime}$ & $33^{\circ} 46.43^{\prime}$ & no br. & 5.03 & 51.4 & 5.1 & -33.8 & & B \\
\hline \multicolumn{10}{|c|}{ TTR-4 (R/V Gelendzhik), Cobblestone area (Limonov et al. 1995) } \\
\hline $160 \mathrm{G}$ & $20^{\circ} 48.6^{\prime}$ & $36^{\circ} 08.9^{\prime}$ & 0.15 & 1.40 & 74.0 & 9.5 & -24.0 & 69.96 & $\mathrm{H}$ \\
\hline $162 \mathrm{G}$ & $20^{\circ} 51.3^{\prime}$ & $36^{\circ} 00.8^{\prime}$ & 0.2 & 2.17 & $72.6^{\mathrm{b}}$ & $5.4^{\mathrm{b}}$ & $-24.6^{\mathrm{b}}$ & 70.44 & $\mathrm{H}$ (specular) \\
\hline $164 \mathrm{G}$ & $20^{\circ} 53.0^{\prime}$ & $35^{\circ} 55.3^{\prime}$ & 0.2 & 1.95 & 81.9 & 3.9 & -20.6 & 30.47 & $\mathrm{H}$ \\
\hline $161 \mathrm{G}$ & $20^{\circ} 50.6^{\prime}$ & $36^{\circ} 02.0^{\prime}$ & no br. & 3.89 & 55.4 & 4.4 & -32.1 & & B \\
\hline $163 \mathrm{G}$ & $20^{\circ} 51.9^{\prime}$ & $35^{\circ} 58.6^{\prime}$ & no br. & 3.73 & 62.6 & 4.7 & -29.0 & & M \\
\hline
\end{tabular}

Columns numbering: \#, Core number; Lon, Longitude (d:m:s E); Lat, Latitude (d:m:s N); MBC, Depth of mud breccia contact (mbsf); no br., no mud breccia; TCL, Total core length (mbsf); GL, Reflectivity (gray level); DEV, Std Dev; RI, Retrodiffusion Index (dB m ${ }^{-2}$ ); GA, Grazing angle $\theta_{g}$ (degree) for the insonified core location (only for cores with mud breccia); RL, Reflectivity level, B, Background; M, Medium; H, High

a See Ryan et al. (1982, Fig. 4)

b Because of specular perturbation, reflectivity was taken on a nearby location on the same mud flow (see text and Fig. 5-1b) 
Fig. 5 Cobblestone area 1a and $1 b$ (see Figs. 2 and 4) with detected mud flows (high and medium reflectivity) and the location of sedimentary cores. Empty circles and diamonds correspond to cores which did not recovered mud breccia. Filled circles and diamonds are cores that reached mud breccia contact, and show its depth in centimetres below sea floor.

Square pointed by an arrow indicates the location where the reflectivity for Core $162 \mathrm{G}$ was taken. (R1a and R1b) Original EM-12 256 gray levels reflectivity images equalized for the corresponding areas.

Sampling locations are shown by diamonds and circles

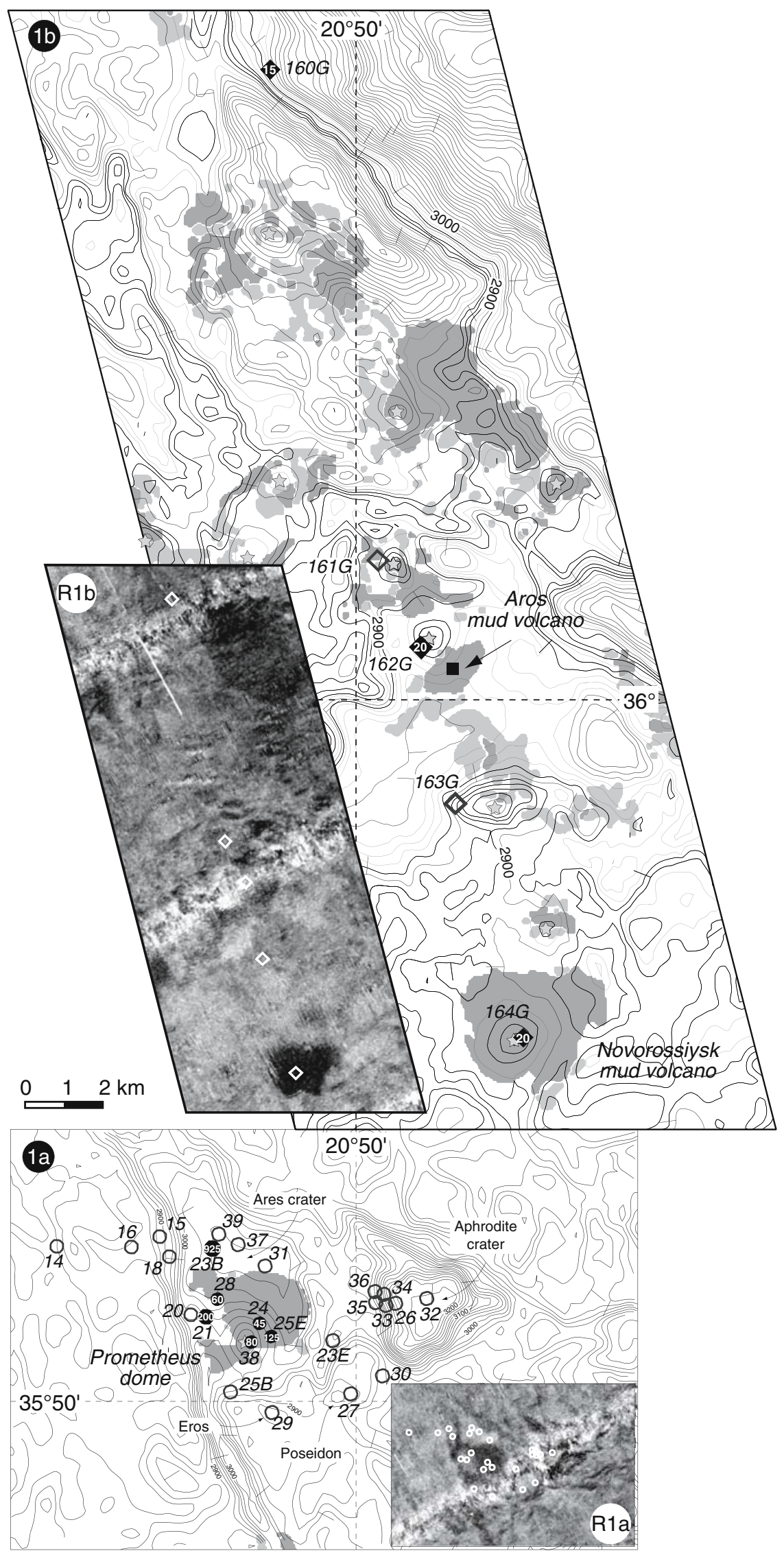




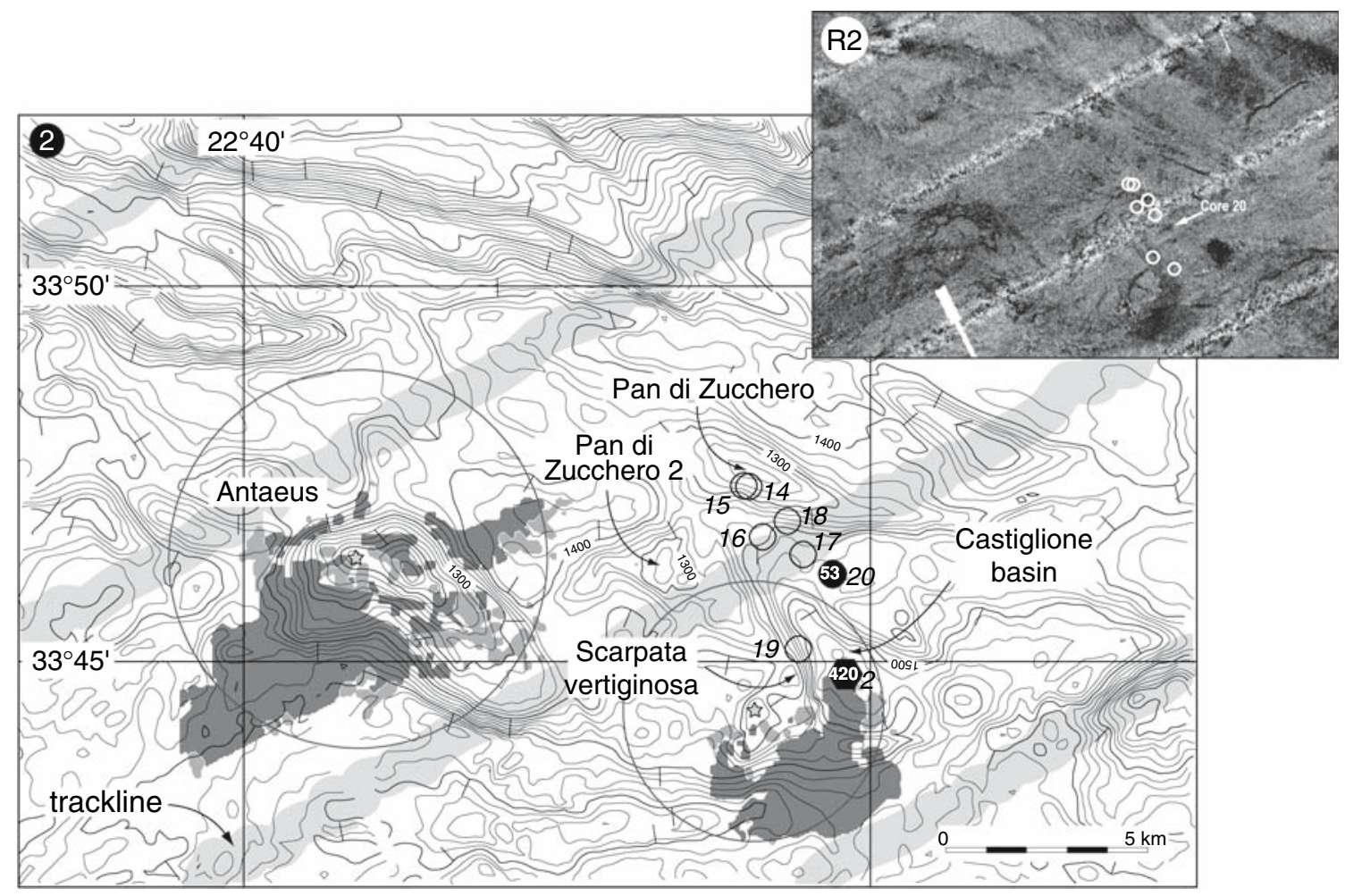

Fig. 6 (2) Pan di Zucchero area with detected mud flows (high and medium reflectivity, in dark and medium gray, respectively) and the location of collected cores. Circles: $R / V$ Meteor ' 93 cores; Hexagon: $R / V$ Bannock '89 core (Hieke et al. 1996). Empty circles corresponds to cores which did not recovered mud breccia. Filled circle and hexagon are cores that reached mud breccia contact, and show its depth in centimetres below sea floor. Empty star: inferred emission point (the circle centered on it roughly figures the relative importance

extruded mud. The maximum surface of mud flows around a single mud volcano is above $78 \mathrm{~km}^{2}$, which is enough to cover a city the size of Paris. This volcano is located north of Antaeus (Pan di Zucchero area). Table 3 shows the characteristics of the 215 mud flows. The average area of a mud flow is ca. $9 \mathrm{~km}^{2}$.

\section{Distribution and distance to backstop}

The mud volcanoes are unevenly distributed on an arcuate chain, concave northward, close to the top of the Mediterranean Ridge. The distribution shows two main active provinces, a Cobblestone Area s.l., and a Pan di Zucchero s.l.. We note that these provinces cover much larger surfaces than those originally described. The area between these provinces seems to be less active (Fig. 8c). A third and smaller belt of mud volcanism follows the top of the Mediterranean Ridge further north towards the junction with the Calabrian Prism. Notice that the portion of the Calabrian Prism surveyed is spotted with mud flows of insignificant extent compare to the western Mediterranean of the mud volcano). Mud flows: High reflectivity (dark grey) and medium reflectivity (medium grey) are shown. Light grey strips across the figure represent roughly the extension of the specular reflexion (blind path) during data acquisition. Bathymetric contours every 20 m. R2: Original EM-12 256 gray levels reflectivity image equalized. Sampling locations are shown by circles, except for Core 20, where the arrow indicates the small patch of reflectivity corresponding to its sampling location

Ridge. The two large provinces show slightly different populations: the Cobblestone area s.l. is more densely populated with smaller mud flows, while the Pan di Zucchero area s.l. shows more scattered and bigger objects.

A first striking result is that mud volcanism is concentrated in a rather narrow belt, emphasizing the concept of a mud diapiric belt (Limonov et al. 1996). To quantify this effect, we plot the longitudinal distribution of mud flows (Fig. 8a) and the total extruded mud surface (Fig. 8b), both as a function of the distance to the prism-backstop boundary. West of $22^{\circ} \mathrm{E}$, the mud is expulsed in a narrow (ca. $35 \mathrm{~km}$ ) band, restricted to the southwest of the prism backstop boundary. East of $22^{\circ} \mathrm{E}$, mud flows are more evenly distributed, still the largest of them being located within $35 \mathrm{~km}$ from the prism-backstop boundary. The resulting total extruded mud distribution (Fig. 8b) is an asymmetric bell-shaped curve, with a clear threshold around $35 \mathrm{~km}$. We use this threshold to separate two mud volcanism domains: an inner domain covering the wedgebackstop contact, and an outer domain that corresponds to the mud volcanism scattered in the rest of the accretionary prism (Fig. 7). We note that in Fig. 8b there is no mud 


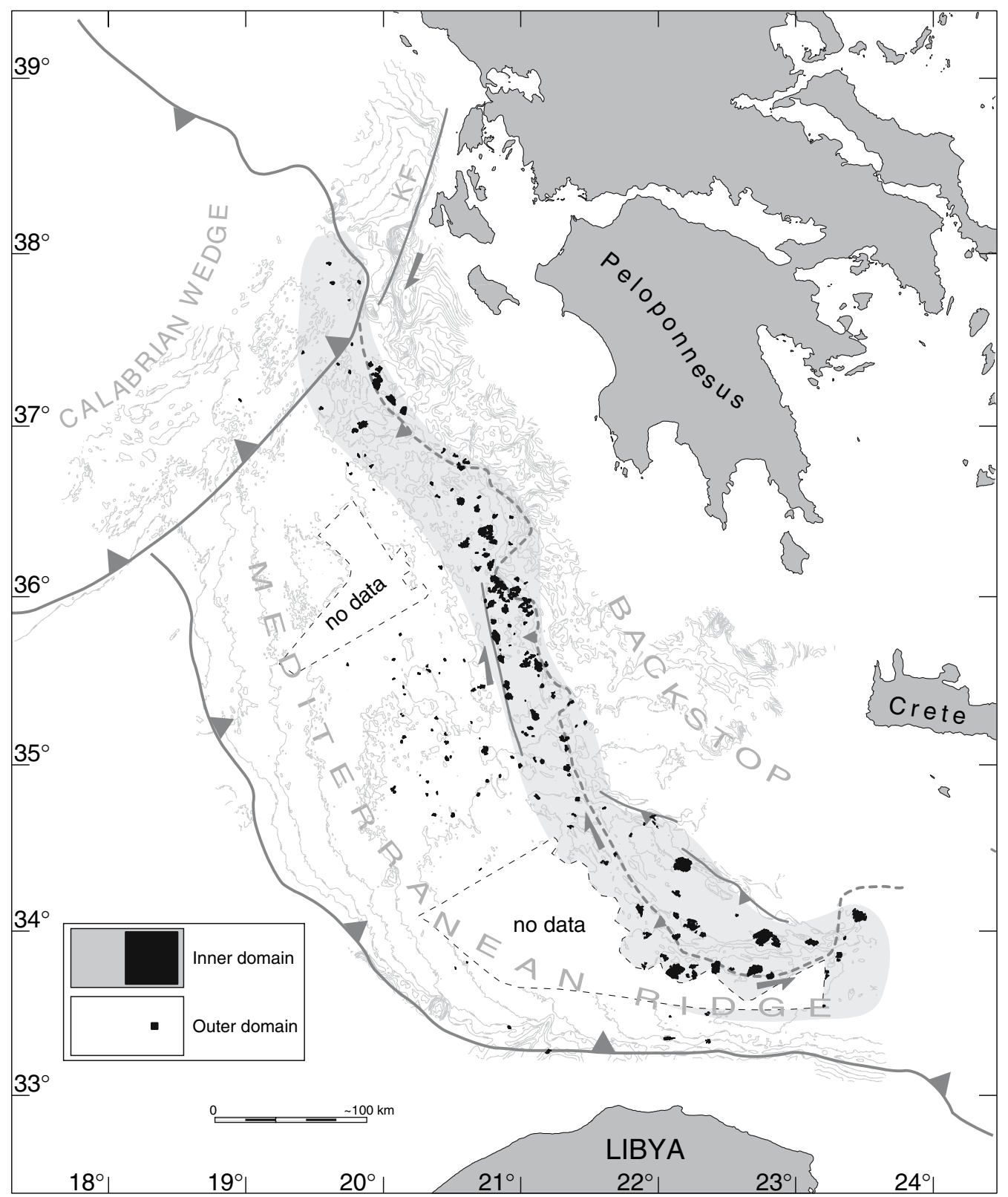

Fig. 7 Detected mud flows in the western Mediterranean Ridge, in black. Dashed line: Prism-backstop boundary. KF: Kephalonia fault. For the Mediterranean Ridge, inner and outer domains encompass mud volcanism closer than, and farther than $35 \mathrm{~km}$ from the prism

volcanism farther than $128 \mathrm{~km}$, indicating very little activity within the post-Messinian wedge.

Table 2 shows the statistics for the two domains. About $76 \%$ of the mud flows are located in the inner domain, and contribute to $92 \%$ of the total mud extrusion surface. The largest mud flows are also located in the inner domain. Mud flows are significantly smaller in the outer domain (prism), the size of the volcanoes varying mainly between $0 \mathrm{~km}^{2}$ and $5 \mathrm{~km}^{2}$. The average mud flow area is at least four times smaller than in the inner domain $\left(2 \mathrm{vs} .9 \mathrm{~km}^{2}\right)$. backstop boundary, respectively. Black squares represent the total mud flow surface at true scale, for each domain (Inner domain: $36.8 \times 36.8 \mathrm{~km}^{2}, 92 \%$ of the total mud surface; Outer domain: $11.1 \times 11.1 \mathrm{~km}^{2}, 8 \%$ of the total mud surface)

Age of the mud flows

The age of the flows detected by sonar imagery is obviously much younger than the age of the volcanoes. Flows are rapidly buried beneath a thin layer of hemipelagic sediments, at a depth greater than the detection limit of the sonar. This implies that we detect only the latest flows related to the recent activity of the volcano. A simple acoustic model was explored by Mitchell (1993), using GLORIA sidescan sonar data to estimate sediment 
Table 2 Statistics on mud volcanism over the western Mediterranean Ridge. Inner and outer domains are those defined in Fig. 7

Total extruded mud: $1474.3 \mathrm{~km}^{2} \quad$ Inner domain (Transpressional to pre-collisional settings) Outer domain (Intra-prism area)

Total number of flows: 215

\begin{tabular}{lll}
\hline Number of flows & 163 & 52 \\
Maximum size (extruded mud, $\left.\mathrm{km}^{2}\right)$ & 78.43 & 14.18 \\
Average size (extruded mud, $\left.\mathrm{km}^{2}\right)$ & 8.29 & 2.36 \\
Total extruded mud $\left(\mathrm{km}^{2}\right)$ & 1351.42 & 122.90 \\
$\%$ Surface of total extruded mud (measured) & $92 \%$ & $8 \%$ \\
$\%$ Volume of total extruded mud (calculated) & $96 \%$ & $4 \%$ \\
\hline
\end{tabular}

Surface percentages were measured. Volume percentages were calculated following simple geometrical assumptions stated in Appendix A

thickness from the level of backscatter. The model involves a highly backscattering surface (basement or mud breccia) overlain by a thin layer of fine-grained sediments. The effective backscattering strength (i.e. the signal recorded back to the sonar) is merely dependant on the backscatter properties of the rough surface, $\mathrm{BS}_{v}$, diminished by the amount of signal attenuated along the two-way path of the wave into the soft sediments:

$\mathrm{BS}=\mathrm{BS}_{v}\left(\theta_{g}\right)+20 \log \left(T_{\mathrm{ws}} T_{\mathrm{sw}}\right)-\frac{2 \alpha_{\mathrm{dB}} h}{\sin \theta_{g}}$,

where $\theta_{g}$ is the grazing angle, $\alpha_{\mathrm{dB}}$ is the attenuation coefficient, expressed in $\mathrm{dB} \mathrm{m}^{-1}$, and $h$ is the thickness of the sediment layer. The quantity $20 \log \left(T_{\mathrm{ws}} T_{\mathrm{sw}}\right)$ (transmission coefficients across the water-sediments interface) has been calculated using the parameters defined in Volgin and Woodside (1996) and shows little variations for $\theta_{g}$ comprised between $30^{\circ}$ and $70^{\circ}$ (see also the discussion in Mitchell (1993)). Derivating Eq. 1 with respect to depth leads to:

$\frac{\mathrm{dBS}}{\mathrm{d} h_{e}}=-2 \alpha_{\mathrm{dB}}$,

where $h_{e}=h / \sin \theta_{g}$, and is the effective thickness of sediments traveled by the acoustic ray. It directly gives an estimate of the attenuation $\alpha_{\mathrm{dB}}$, supposed to be constant with $h$.

Figure 9a shows the cores that recovered mud breccia, and the depth of mud breccia first contact in the core. We plot the backscatter strength BS as a function of the effective thickness $h_{e}$. The plot shows the boundaries of our classification of reflectivity, namely high, medium and background. Eight of a total of 12 cores reached mud breccia at depths less than one metre. They all fall into the medium and high reflectivity domains. The remaining four cores reached mud breccia at depths greater than $2 \mathrm{~m}$.
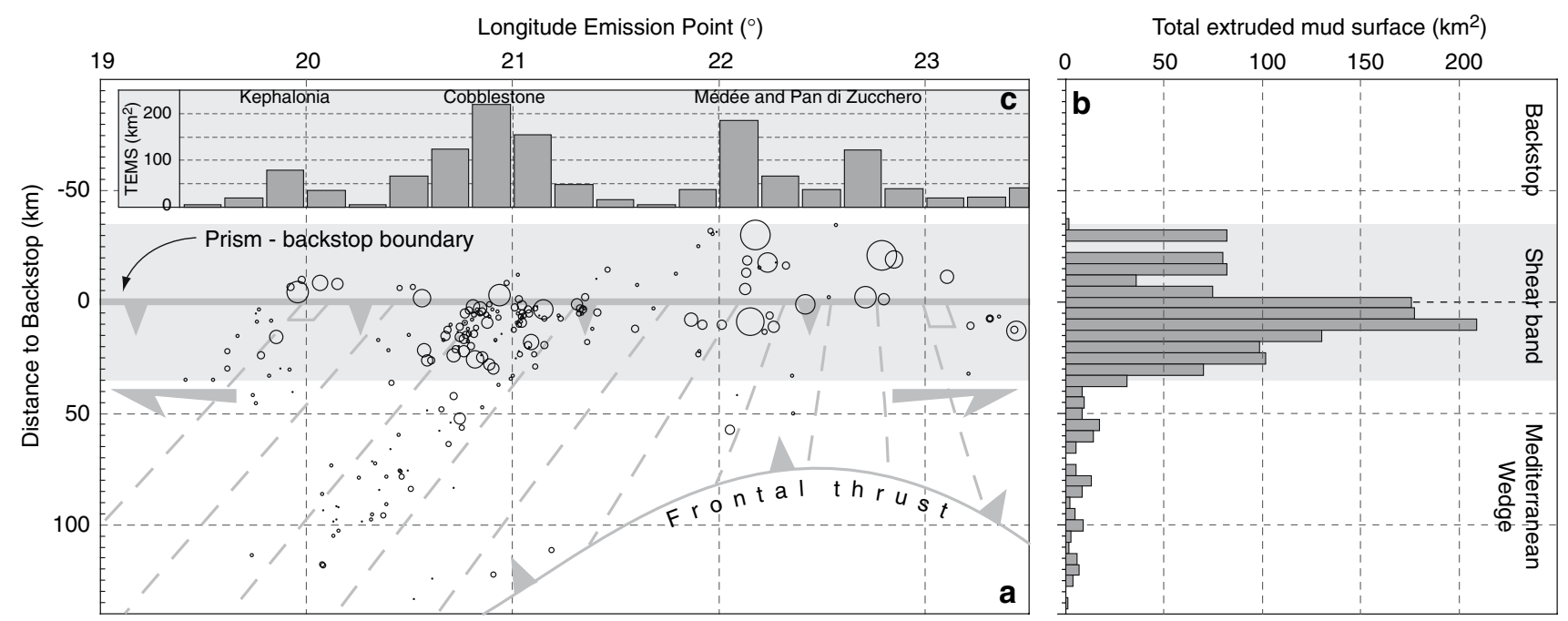

Fig. 8 (a) Plot of the distance to backstop as a function of the longitude of the mud volcano emission points. Bubble size is proportional to the mud extrusion surface for each mud flow. Null distance is the prism-backstop boundary, negative values cover the backstop area while positive values cover the wedge area. We schematically show the $70 \mathrm{~km}$ wide-shear band at the prism-backstop contact. Dashed lines are perpendicular to the backstop. The frontal thrust is also schematically indicated. (b) Total extruded mud surface as a function of the distance to backstop, binned every $5 \mathrm{~km}$. (c) Total extruded mud surface as a function of the longitude, binned every $12 \min$ 

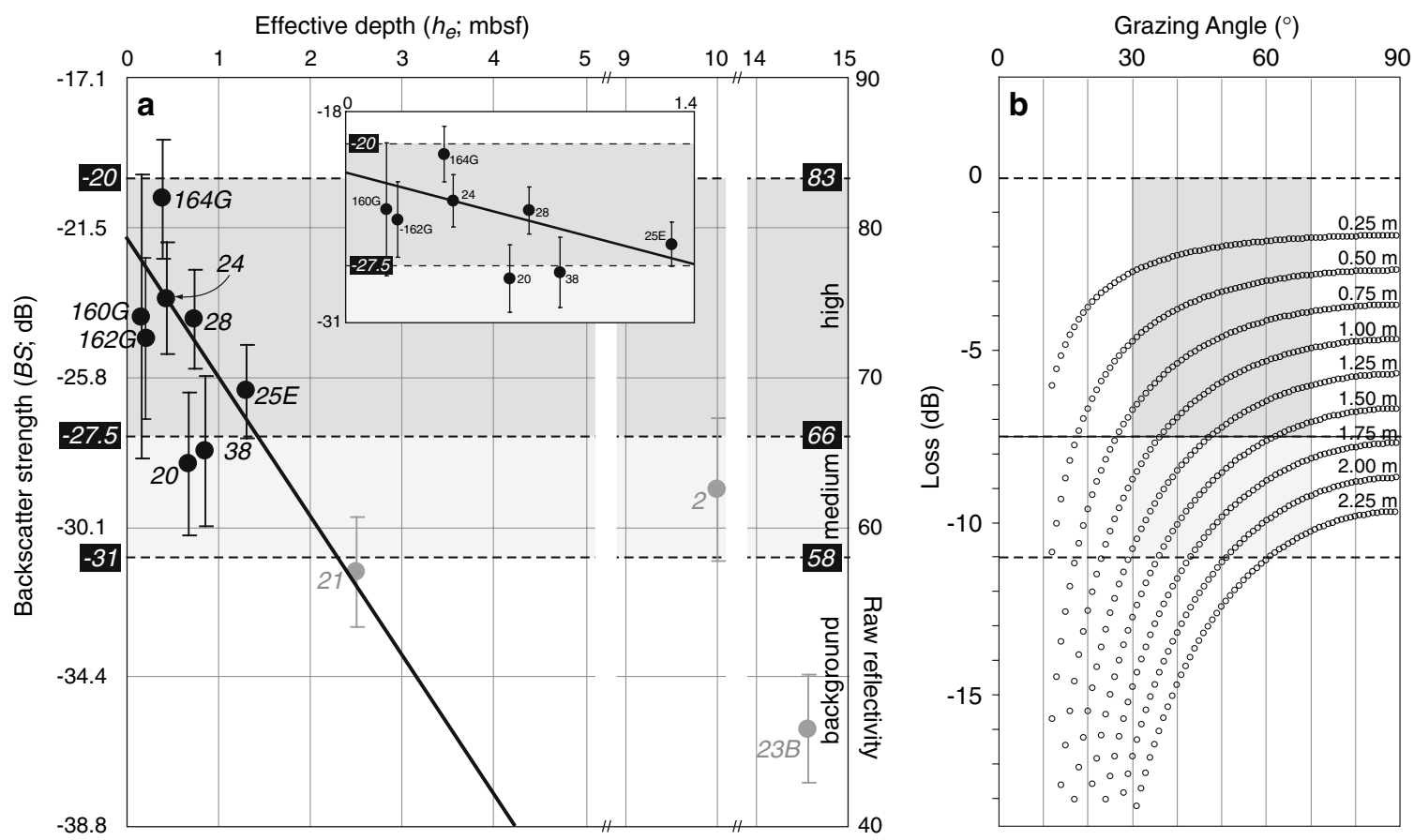

Fig. 9 (a) Backscatter strength of the seafloor plotted against depth of mud breccia contact. The backscatter strength is averaged over $500 \mathrm{~m}^{2}$ centred on the core location (uncertainty is one standard deviation). Only the black dots were used for the fit. The shaded dots are considered to be within the background noise. The limits are the original medium (128) and high reflectivities (192) limits,

Three of them fall in the background domain. Core 2 (Castiglione Basin) shows a medium backscatter strength but we still consider it as part of the background noise because of an overall higher average reflectivity of the Pan di Zucchero area.

A first-order interpretation is that mud breccias at sub-seafloor depths of less than $2.25 \mathrm{~m}$ do contribute to the backscattering strength, whereas deeper mud breccia signal, if any, is lost into the background signal. Unfortunately, the interval $125-200 \mathrm{~cm}$ is not sampled. The plot also shows that in the $0-125 \mathrm{~cm}$ interval, reflectivity is rapidly decreasing with depth. A least-squares fit using the constant attenuation model (Eq. 1; see Appendix C) through these data gives an attenuation $\alpha$ of $2.0 \pm 0.7 \mathrm{~dB} \mathrm{~m}^{-1}$ in our data depth interval $(20-125 \mathrm{~cm})$. Converted into $\mathrm{dB} \mathrm{m}^{-1} \mathrm{kHz}^{-1}$, equivalent to Hamilton's constant $k$ (Hamilton 1972), we find $k=0.16 \pm 0.06 \mathrm{~dB}$ $\mathrm{m}^{-1} \mathrm{kHz}^{-1}$. These values are in the range of those quoted by Gorgas et al. (2002) in superficial unconsolidated finegrained sediments.

We note that the maximum depth of detection of the sonar is different than the depth of penetration: a mud breccia can eventually be reached at depth below the detection level, but the corresponding signal is lost in the background level. We estimate from Fig. 9 that the recalculated for the raw (not equalized) image, and their corresponding backscatter strengths (in a 256 gray levels scale). The inset is a enlargement between $h_{e}=0$ and 1.4, showing the linear fit. (b) Loss of sound energy from attenuation in sediments as a function of grazing angle for different thicknesses of sediment layer, calculated for $\alpha=2.0 \mathrm{~dB} \mathrm{~m}^{-1}$

maximum depth of detection lies between $100 \mathrm{~cm}$ and $225 \mathrm{~cm}$. This plot further suggests that the backscatter strength is correlated to the depth of burial of the mud breccia layer (i.e. the thickness of the overlying pelagic sediments), at least in the Cobblestone area s.l.. The nature of the pelagic sedimentary cover may account also for variations in reflectivity intensity, especially for the

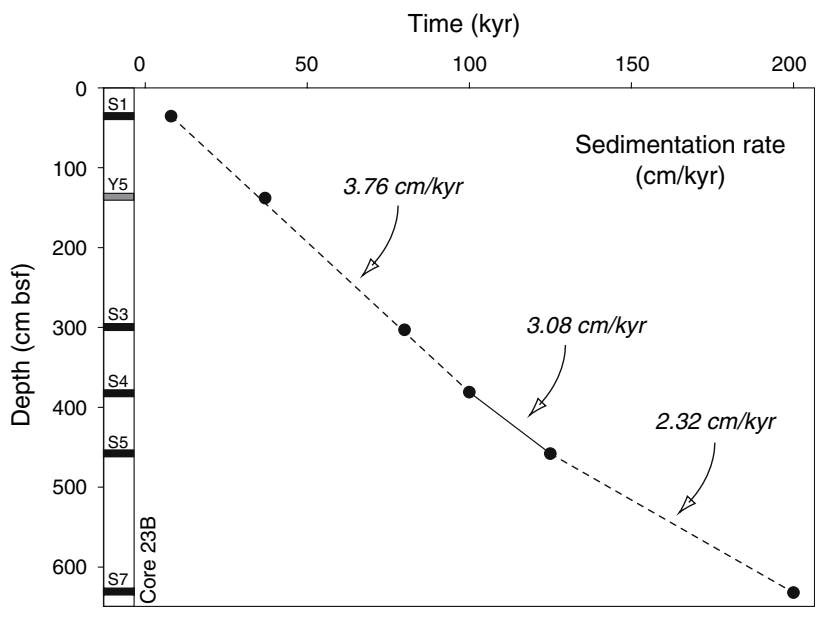

Fig. 10 Sedimentation rates calculated from the location of sapropels S1 to S7, and tephra Y5, in Core 23B 
background reflectivity, as we see a striking difference in the overall reflectivity between the Cobblestone area (Fig. 5-R1a and R1b) and the Pan di Zucchero area (Fig. 6$\mathrm{R} 2$ ). However, we think that this effect is minor in the interpretation of backscatter intensities. Another cause of variation in the reflectivity pattern is the nature of the mud breccia, and particularly the size and shape of the included clasts, which can increase the roughness of the sedimentbreccia interface. The mud breccia recovered in the cores used in the present study (see Tables 1 and 2) contains generally $10-15 \%$ of angular to subrounded, millimetric to centimetric clasts. The maximum size was found to be $7 \mathrm{~cm}$ for Cobblestone area, and $5 \mathrm{~cm}$ for Pan di Zucchero area, which is close to the probable maximum size of clasts which can be recovered by coring. However, it is known that clasts in mud breccia can reach much bigger sizes. During ODP Leg 160, Formation MicroScanner downhole geophysical $\operatorname{logs}$ showed clasts of up to $50 \mathrm{~cm}$ in size (Robertson and Shipboard Scientific Party 1996), and during the fifth cruise of the Training-Through-Research program, underwater video encountered blocks larger than $5 \mathrm{~m}$ across inside a mud volcano crater (Cronin et al. 1997). Although we cannot rule out that these variations impact the reflectivity level, the depth of burial seems to be the first order effect (see Fig. 9a).

Figure 10 shows the sedimentation rate for the last 200,000 years calculated from the positions of sapropels $\mathrm{S} 1$ to S7 and tephra Y5 in Core 23B. The ages of the markers were taken from Kroon et al. (1998). For the last 100,000 years, the sedimentary rate is $38 \mathrm{~m} / \mathrm{m} . \mathrm{y}$. The potential maximum depth of detection of the sonar being $225 \mathrm{~cm}$, we suggest that we have detected all mud flows younger than 60,000 years. The deepest mud breccia contact observed in the cores is at $125 \mathrm{~cm}$ (Core 25E; Ryan et al. (1982)), immediately overlain by tephra Y5 (37,000 years). Consequently, amongst the 215 identified mud flows, the age of the last eruption varies between 0 (subactive) and 37,000-60,000 years.

\section{Discussion}

Episodicity of mud eruption

Mud volcanoes of the Mediterranean Ridge have been described as active or inactive on the basis of various characteristics: age of the mud flows, type of mud breccia, presence of fluids and gases expulsion, amount of subsidence, strength of acoustic reflectivity. We interpret these to relate to a wide range of timescales and physical processes. The episodicity of eruptions has been proven by coring (reworking of mud breccia), drilling (long period of pelagic sedimentation in between mud flows), and numerical modeling (Kopf and Behrmann 2000). Schematically, a resting period greater than $10^{5}$ years was found in Milano volcano between two mud extrusion periods (Robertson and Shipboard Scientific Party 1996), while reworking of mud breccia in metres-long cores indicates episodicity probably shorter than $10^{3}$ years. Similarly, mousse-like mud breccia, because of its highly gaseous nature, may be an even more recent sign of activity. Such type of mud breccia has been recently found outcropping in a small number of mud volcanoes, Napoli and Milano (Robertson and Shipboard Scientific Party 1996), Dublin and Stoke-on-Trent (Ivanov et al. 1996a) and in our area Novorossyisk (Limonov et al. 1995). All of them are characterized by strong reflectivity patterns, except Napoli, which shows an almost blank pattern, with a marked moat surrounding a darker center (Kopf et al. 2001, their Fig. 4A). Significant gas/fluid emission activity has been detected on this mud volcano during several submersible dives (Aloisi et al. 2000; MEDINAUT/MEDINETH Scientific Party 2000), and a pure methane content measured as high as 900,000 ppm in the cores during ODP Leg 160 (Emeis et al. 1996, Site 971). These unique characteristics strongly suggest that Napoli volcano has been active very recently $\left(1-10^{2}\right.$ years ?). Reflectivity data, on the other hand, span an age interval which is dependent on the detection depth of the sonar and on the rate of sedimentation above the latest mud flow, and typically gives a timespan of the order of $10^{4}$ years.

In our case, a sedimentation rate of $38 \mathrm{~m} / \mathrm{m}$.y. causes the imprint of a mud volcano averaging 50-200 $\mathrm{m}$ in height to disappear in 1.3-5.3 m.y. from the seafloor. We suggest below that the initiation of mud volcanism may be as young as $2 \mathrm{Ma}$. We thus argue that we have detected most of the population of mud volcanoes, either as high reflectivity patches, or as rounded features not associated with high backscattering but suspected to be mud volcanoes. In the following text, we suggest that the latter may represent $5-10 \%$ of the entire population. They correspond to the rare mud volcanoes that did not erupt during the time span covered by the sonar ( 0 to $37,000-60,000$ years).

To gain insight into the episodicity of mud eruption, let us assume that the recurrence time for mud volcano eruption is $\tau$ (in other words, one single eruption for the entire population of $N$ volcanoes, every $\tau$ ). We further assume that each volcano has the same equal probability $p=1 / N$ to erupt. We use a simple binomial distribution law to find after how many draws in the entire population, we reach a proportion of negative draws (no eruption) equal to $5 \%$ and $10 \%$. We find a number $n$ of 804 and 549 draws, respectively. The time interval is $\Delta t=37,000-60,000$ years. As $\tau=\Delta t / n$, the recurrence time for a mud volcano eruption ranges between 60 years and 88 years. Using the same law, the most probable number of eruptions for one single 
volcano during the $\Delta t$ period is $2-3$. The probability to have more than six eruptions is below $1 \%$. These figures are compatible with our observation of multiple flows at at least one mud volcano, based only on reflectivity contrasts. They suggest that the order of magnitude for the resting time at one single volcano is $10^{3}-10^{4}$ years. This is compatible with the long resting period observed for the Milano volcano. This recurrence time is significantly larger than the eruption rates reported for the Azerbaijan mud fields (Mellors et al. 2007).

\section{Tectonic control on mud volcanism}

The Mediterranean Ridge is actively growing in front of a continental crustal backstop, as a typical accretionary prism. The present-day convergence rate derived from GPS is above $30 \mathrm{~mm} / \mathrm{year}$ (Mcclusky et al. 2003). It is generally agreed that the present-day kinematic framework was established during the Plio-Pleistocene (Armijo et al. 1999), in relation with the onset of motion of the Anatolian microplate and the activation of the North Anatolian fault. Although the timing of initiation of the Hellenic subduction is still debated, the Mediterranean wedge is generally considered not older than Miocene (Kastens 1991). The frontal portion of the wedge (not more than $80 \mathrm{~km}$ wide) is post-Messinian, implying that the material involved in the accretion is a mixture of post-Messinian sediments and Messinian evaporites originally deposited in the trench. The rest of the wedge (about two thirds) is essentially built by pre-Messinian sediments. A particularity of the presentday subduction is the V-shape geometry of the tip of the resisting backstop, with a NW trending western branch and NE trending eastern branch (Le Pichon et al. 1995, 2002; Costa et al. 2004; Kreemer and Chamot-Rooke 2004). Northward motion of Africa with respect to the backstop implies high obliquity of the convergence along the entire Mediterranean Ridge. This oblique convergence is accommodated by shear partitioning on both branches of the Mediterranean Ridge (Kreemer and Chamot-Rooke 2004; Costa et al. 2004). Shearing is active preferentially at the wedge backstop contact, and is respectively dextral and sinistral over the western and eastern branches of the Mediterranean Ridge.

The mud volcanic belt closely follows these dextral and sinistral shear bands. The Cobblestone Area s.l. coincides with a major NNW-SSE dextral strike-slip fault zone, while the Pan di Zucchero Area s.l. exactly covers the leftlateral strike-slip zone and associated en-échelon folds that form the very top of the Mediterranean Ridge. At the scale of the Eastern Mediterranean basins, there is thus a clear link between the main active fault zones and mud expulsion. The common interpretation is that the source for the mud is within the wedge (Robertson and Kopf 1998b; Kopf 2002), and that rapid stacking of high-porosity sediments ultimately leads to over-pressures and expulsion.

An alternative is that the mud reservoir is located at the backstop-wedge contact, as discussed below. In both cases, active faults then act as preferential channels for mud expulsion.

At a local scale, mud flows of the Mediterranean Ridge are systematically associated with faults. Detailed structural mapping shows that mud volcanoes are preferentially located at the tip of the faults, or more generally in the zones of fault interactions (restraining or releasing bends, faults intersections). This is not specific to the Mediterranean Ridge outflows, as evidenced by the worldwide compilation of fluid flow outlets under various tectonic regimes made by Curewitz and Karson (1997). Simple faults models predict accumulation of stress and strain at faults tips and/or intersections, leading to localized damaging. Several examples are shown in Fig. 4. Several volcanoes punctuate a more or less linear strikeslip fault, each of them associated with small step in the major trend. One of them coincides with a releasing bend, leading to the formation of a small pull-apart type basin (right lateral). The main edifice is conical and located right in the center of the basin, while the erupted material fills the depression.

Most of these mud volcanoes were not surveyed by means of seismic reflection methods. Apart from areas that have been extensively covered, it is actually quite rare that a seismic profile runs across a mud volcano, and even more unlikely that it cuts through the mud extrusion conduit. The conduit itself is probably small compared to the overall size of the mud volcano, and it may be irregular or oblique. Figure 11 shows the IMERSE 01 profile, that crosses a mud volcano immediately south of the Cobblestone area (Westbrook and Reston 2002). Several features, often described as typical of a mud volcano can be seen: the mud dome with the depression ring around it, the reflectors below interrupted and dipping downward, and the transparent material forming the core of the volcano. Away from the mud volcano, reflectors are sub-horizontal and organized into a limited number of stratigraphic sequences. A thin and very flat reflector is ubiquitously recognized $200 \mathrm{~ms}$ below the surface. Based on seismic velocities and sedimentation rates, we estimate that this reflector marks the MiocenePliocene boundary. Immediately below, we find a thick body of well-stratified sediments above another thick but poorly stratified sequence. Seismic traces show a polarity inversion at the base of this latter sequence, around $5 \mathrm{~s}$ two-way travel time (TWTT), that we interpret as the base of the Messinian series. The two large bodies would thus correspond to the upper evaporites resting on the 

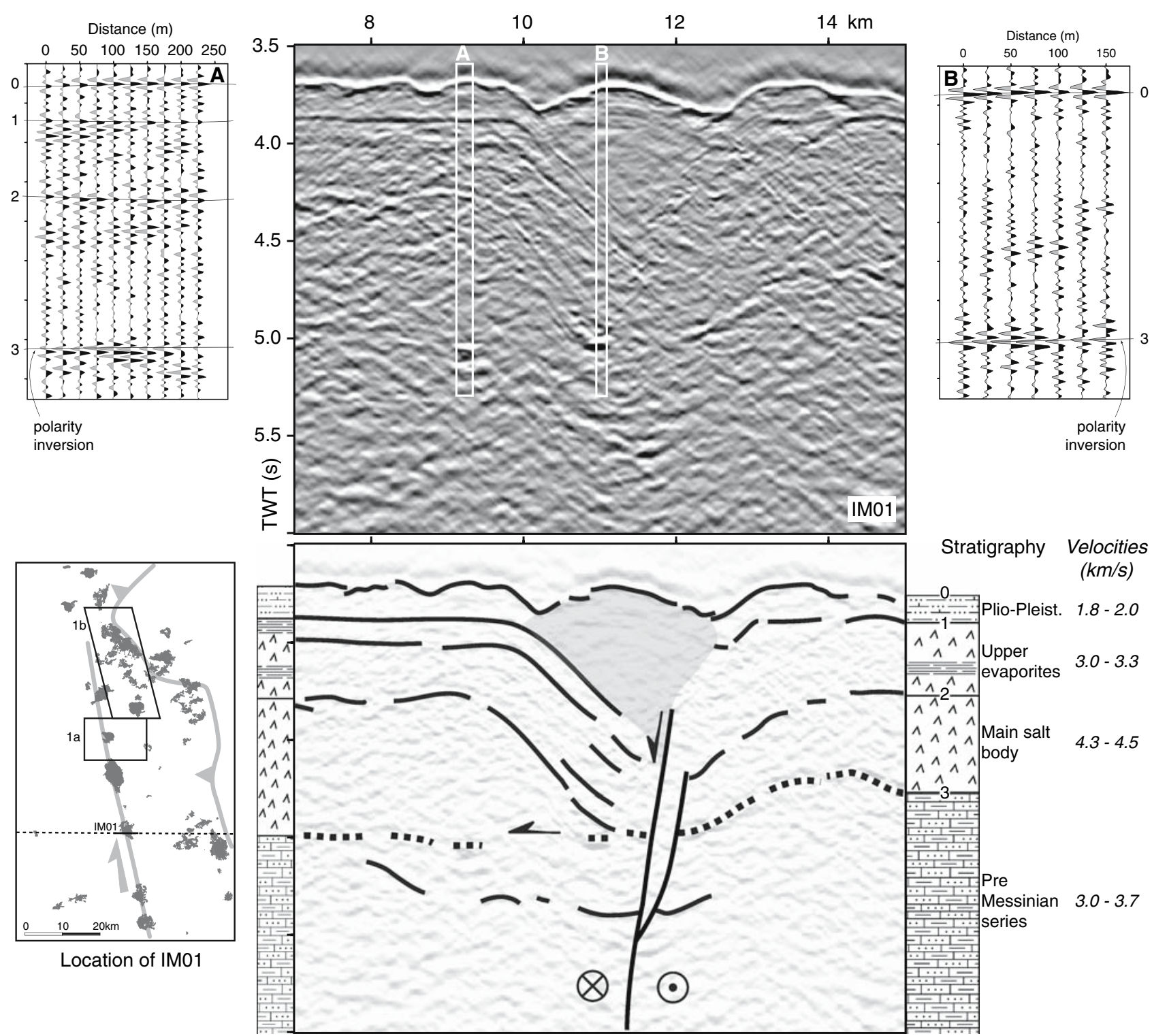

Fig. 11 Top: Extract of IMERSE profile IM01 (migrated section) across one mud volcano located south of Cobblestone area 1a along one of the main strike-slip faults. A and B: polarity inversion at the

main salt body. Our tectonic interpretation is that a small releasing relay along the major strike-slip fault leads to normal faulting, with the base of the Messinian salt body acting as a décollement. In detail, the upper Messinian sequence shows fanning of the reflectors towards the fault, indicating that it was active during Messinian time. The erupted material is quite thick and seems to rest above the top reflector. The likely scenario is that strikeslip tectonism induced normal faulting, which in turn ultimately lead to mud eruption. This suggests that this mud volcano is post-Pliocene in age. This is compatible with the inferred age of the Milano (about $1.5 \mathrm{Ma}$ ) and Napoli (older than $1 \mathrm{Ma}$ ) domes (Robertson and Kopf 1998b). boundary between the Messinian salt and the pre-Messinian series. Bottom: tentative geological interpretation; dotted line: base of the salt body inferred from mapping of the polarity inversion

Messinian evaporites

Messinian evaporites are generally considered to play a major role in controlling mud volcanism over the Mediterranean Ridge. They also have been proven to be involved in mud volcanism genesis in contexts other than subduction (Netzeband et al. 2006). Low permeability evaporites strata act as seals leading to high pressures in the sediments below (Reston et al. 2002b; Netzeband et al. 2006). The paradox is two-fold for the Mediterranean Ridge. First, mud volcanism is most intense in the crestal portion of the ridge, where the Messinian should be absent considering that the ridge (i.e. topographic relief) formed in Miocene times and perhaps even before (Kastens 1991). 
Second, maximum mud output occurs at a great distance from the toe of the prism where dewatering is almost completed (Chamot-Rooke et al. 2005a). The Messinian wedge itself, i.e. the portion of the wedge that formed in post-Messinian times and contains thrusted Messinian evaporites and PlioQuaternary, is restricted to the outer $80 \mathrm{~km}$ of the accretionary prism (Chaumillon et al. 1996). However, Messinian evaporites are not restricted to the outer post-Messinian wedge. Salt basins have also been found further up-slope, including the crestal area of the Mediterranean Ridge (Reston et al. 2002a). The base of the Messinian was actually recognized at several places based on the polarity inversion generated by the inverse velocity gradient at this boundary (Fruehn et al. 2002). The Messinian thickness reaches locally several kilometers. Figure 11, which is a section obtained close to the top of the ridge, shows a total thickness of the main body salt plus the Upper Messinian evaporites of about 2,000 m. During the Messinian salinity crisis, deep basins existed in a fore-arc position, probably at the southern edge of the continental Hellenic margin. Relief was thus inverted in post-Messinian times. Our data indicate that mud volcanism is indeed closely related to these Messinian evaporites basins: mud escapes are preferentially located at the edges of these basins, where the salt layer was either thinner or broken, the latter being the result of extension (Costa et al. 2004) or strike-slip (Chamot-Rooke et al. 2005a), or both.

Our conclusion is that the Messinian seals do not relate to the post-Messinian incorporation of evaporites into the wedge, but to in-situ sedimented Messinian sediments in small and deep basins that have been uplifted rather than accreted and transported.

\section{Source of mud and clasts}

A full discussion on the provenance and age of clasts and matrix is found in Akhmanov (1996), Robertson and Shipboard Scientific Party (1996), Robertson and Kopf (1998a) and Akhmanov et al. (2003). Drilling undisputedly brought important new data. ODP Leg 160 (Sites 970 and 971) drilled into two contrasting mud volcanoes: the Milano volcano, which is conical, and the Napoli volcano, which is flat-topped. The deepest holes reached $200 \mathrm{mbsf}$. Both volcanoes were active prior to at least 1.5-1.75 Ma. Napoli is still active, but Milano is considered to be dormant. The matrix includes dominantly Middle Miocene age nannofossils and foraminifer assemblages, but Eocene and Oligocene ages are also found. Clasts in both volcanoes contain (1) Burdigalian to Langhian biota and (2) assemblages of Middle Miocene, Oligocene and Eocene ages, together with Cretaceous nannofossils. Sandstone clasts are mainly of plutonic and metamorphic origin, derived dominantly from the North African margin, but also from Crete and adjacent reliefs (Akhmanov 1996; Akhmanov and Woodside 1998; Robertson and Kopf 1998b; Kopf et al. 2000; Akhmanov et al. 2003). Drilling did not totally rule out the possibility that clasts and matrix were derived from the same stratigraphic unit. However, the favored interpretation is that the matrix is dominantly Messinian in age (mud from the early stages of the salinity crisis) and clasts are older Miocene clastic and carbonate units (Robertson and Kopf 1998b). Our interpretation is that the clasts represent reworked material. Detrital units have been described above the main Messinian salt body (Sage et al. 2005), as products of the subaerial erosion of nearby continental rocks of the backstop during lowstands of the Messinian crisis, including the extension at sea of the cretean metamorphic units (Le Pichon et al. 2002). Camerlenghi et al. (2007) recently raised the possibility that the origin of mud volcano clasts in the entire Mediterranean region is the exhumation of olistostromes.

A key point of the discussion is whether the source has been traveling into the wedge or not, either along the décollement (?) (e.g. Kopf and Behrmann 2000, p. 198) or by progressive incorporation into the prism. If the décollement is taken as the plate boundary, then material below has little chance to be accreted into the wedge. The implication is that traveling, if any, can only occur within the wedge itself. The horizontal velocity, then, is only a small fraction of the total convergence rate. A clear demonstration is that the width of the Messinian wedge does not exceed $80 \mathrm{~km}$, which is thus the maximum distance traveled by Messinian material originally deposited in the trench. A second line of reasoning leads to a similar conclusion. Taking the present-day velocity field as steadystate through time (Kreemer and Chamot-Rooke 2004), we can calculate the traveling time, i.e. the time it would take for one sequence deposited into the trench (and later incorporated into the wedge) to enter the area of maximum mud production. The steady-state model is obviously an over simplification. We think however that this model is much closer to reality (for the last few million years) than the kinematics that has been used so far (unrealistic convergence rate of $6 \mathrm{~cm} /$ year in Kopf (1999), probably misprinted as 5-6 mm/year in Kopf (2002), definitely misused as $6 \mathrm{~km} / \mathrm{m} . \mathrm{y}$. - instead of $60 \mathrm{~km} / \mathrm{m}$.y.- - in Kopf (1999)). The traveling time is $19 \mathrm{~m} . \mathrm{y}$. at longitude $20^{\circ} \mathrm{E}$, $11 \mathrm{~m} . \mathrm{y}$. at longitude $21^{\circ} \mathrm{E}$, and $4 \mathrm{~m} . \mathrm{y}$. at longitude $22^{\circ} \mathrm{E}$. These numbers are probably overestimated, since we do not take into account the outward growth rate of the prism. However, based on the limited width of the post-Messinian wedge, we still find it very unlikely that the source for volcanism is a Messinian mud unit transported from the trench, the traveling time being too long for a sizeable portion of the prism. 
That clasts and matrix have not been deeply buried is further demonstrated by petrographic and mineralogical studies. Drilling did not indicate deep-burial diagenesis nor metamorphism of either clasts or matrix, and derivation from relatively shallow levels (less than $7 \mathrm{~km}$ ) was thus suggested (Robertson and Kopf 1998b). This result conflicts with earlier interpretation that one of the potential sources for the matrix could be Aptian-Albian shales (Cita et al. 1981), but was in good agreement with the estimated depth of the décollement level (Camerlenghi et al. 1995). Thermal maturity data initially gave a mobilization depth between $4.9 \mathrm{~km}$ and $7.5 \mathrm{~km}$ (Schulz et al. 1997), but re-evaluation points to an even shallower depth of only about 2 km (Kopf and Behrmann 2000; Kopf et al. 2000). The latter study is based on low vitrinite reflectance, indicating that the material-both clasts and matrix-was not subjected to elevated temperature. To summarize, a Messinian source for mud implies in-situ production close to the wedge-backstop contact rather than transportation through the wedge. The deep Messinian basins that existed close to this boundary prior to the salinity crisis were filled by Messinian evaporites during dessication, the latter providing the necessary seals (Netzeband et al. 2006). The thickness of evaporites compares well with the inferred depth of mobilization (about $2 \mathrm{~km}$ ).

\section{Mud budget for the reservoir hypothesis}

In the previous section, we suggest that the source for the mud is a reservoir that remained close to the backstop contact through time. If we are correct, then convergence has little to do with the overall mud mass budget. The reservoir model implies a "closed" system (the source cannot be renewed), which is at variance with the subduction model in which the input is steady-state. We thus re-examine this budget. Following the simple geometric scheme devised in Appendix B, we estimated the total volume of extruded mud at $657 \mathrm{~km}^{3}$. As mentioned previously, we may have missed some of the volcanoes. However, morphological arguments indicate that at least $80-90 \%$ of them have been discovered. Since we only seek orders of magnitude here, we ignore this potential error. Evenly distributed over the considered $589 \mathrm{~km}$-long of the prism-backstop boundary, this leads to an average rate of $1.1 \mathrm{~km}^{3}$ of mud per kilometer. The thickness of the source layer in the hypothetical mud reservoir can be calculated by dividing this number by the estimated width of the reservoir, that is, the width of the inner domain. The latter varies between $20 \mathrm{~km}$ and $75 \mathrm{~km}$, leading to thicknesses of between $56 \mathrm{~m}$ and $15 \mathrm{~m}$, respectively. In other words, the western Mediterranean mud belt can be explained by depleting an in-situ reservoir of a few tens of meters thick.
The total thickness of the reservoir is unknown, but we conclude that the amount of mud to be mobilized is modest and refilling is not required. The limited thickness of mobilized mud layer is compatible with the limited amount of subsidence, only reported, to date, to happen around each individual mud volcano.

\section{Initiation of mud volcanism}

There are now growing evidence that Eastern Mediterranean tectonics has been affected by significant changes in recent times. Comparisons between global kinematic models based on geology (Nuvel-1A type) and geodetic models (mainly GPS-based) indicate that the convergence of Africa with respect to Eurasia has changed between 3.6 Ma and Present (Calais et al. 2003). The Nubia (Africa)/Eurasia pole of rotation has migrated southward, implying a more westerly oriented motion at slower velocity for the present-day (4-6 mm/year). Whether this change was progressive or sudden has not yet been documented. A significant kinematic change is the onset of motion of the Anatolia-Aegea microplate, pushed laterally in the wake of Arabia northward motion and collision (Mckenzie 1972; Le Pichon et al. 1995). The post-Miocene period is marked by the westward propagation of the North Anatolian Fault towards the Aegean domain (Armijo et al. 1999; Hubert-Ferrari et al. 2002). Propagation may have started in the east at about $10 \mathrm{Ma}$, and by $5 \mathrm{Ma}$ the fault was in the Marmara Sea region (Armijo et al. 1999). Concomitant with the activation of the North Anatolian Fault and the cessation of opening of the Aegean Basin, rapid motion of the Anatolian-Aegean region has resulted in high convergence rate in the Eastern Mediterranean (>3 cm/year), the maximum convergence being reached precisely along the western branch of the Mediterranean Ridge (Le Pichon et al. 1995). The implication for the recent growth of the Mediterranean Ridge is drastic: prior to Anatolia-Aegea escape, the convergence rate did not exceed Nubia/Eurasia motion, and was thus 4-5 times slower than the present-day rate (Kreemer and ChamotRooke 2004). The exact link with the tectonics of the Hellenic Arc is still in debate. The Corinth Gulf, which is presently actively opening at a $>1 \mathrm{~cm} /$ year rate, started opening around 1.0-1.7 m.y. (Sorel 2000; Flotte et al. 2001). At the western end of the Hellenic Arc, the rightlateral Kephalonia Fault may have been activated at about the same time (Nielsen et al. 2001). These recent tectonic changes have been recorded in the field from Peloponnesus to Rhodes. The stress pattern derived from striations measurements on fault planes shows important changes in the Pleistocene (Mercier et al. 1987; Piper and Perissoratis 2003). In the Pliocene and Early Pleistocene extension was 
roughly NE-SW oriented, switching to more or less NS extension in post Middle Pleistocene. A short but intense phase of compression was found in between those two extensional regimes, bracketed between 1 m.y. and 0.7 m.y. (Sorel et al. 1992).

The latest kinematic re-organization thus probably occurred between $1.7 \mathrm{~m}$.y. and $0.7 \mathrm{~m}$.y. If we take the regional events as indicative of the tectonics of the Mediterranean Ridge backstop, then the opening of the Corinth Gulf, the activation of the Kephalonia Fault and the reorganization of the stress pattern along the Hellenic Arc may date the switch from low $(<1 \mathrm{~cm} /$ year) to high convergence rate ( $>3 \mathrm{~cm} /$ year). The result of this change was the activation of strain partitioning at the wedge backstop contact, and the correlative initiation of mud volcanism along this contact. In our model, the major changes thus occurred in the kinematics of the upper plate (motion of the Hellenic backstop), rather than in the lower plate (collision of blocks from Africa). Triggering of mud volcanism would thus relate to the initiation of large-scale transcurrent motion along the Western and Eastern branches of the Mediterranean Ridge in the very recent time, rather than the on-going process of subduction. The proposed age of initiation (younger than $2 \mathrm{Ma}$ ) is compatible with the estimated ages of Milano and Napoli mud volcanoes.

\section{Conclusion}

The seafloor acoustic reflectivity of an area of $600 \times 740 \mathrm{~km}$ in the Eastern Mediterranean that includes $590 \mathrm{~km}$ of the prism-backstop boundary has been analysed to identify the mud flows and their associated mud volcanoes. A total of 215 mud flows were found, covering a total surface of extruded mud of almost $1,500 \mathrm{~km}^{2}$. The inner domain (prism-backstop boundary) represents $92 \%$ of this surface. Using a simple geometric transformation calibrated on a known mud volcano, we convert surface to volume of extruded mud and find that $96 \%$ of the mud is expelled at the wedge-backstop contact.

We calibrate a geoacoustic model modified from Mitchell (1993) using all available cores that recovered mud breccia. The model shows that the maximum depth of mud breccia detection by the sonar is comprised between $125 \mathrm{~cm}$ and $200 \mathrm{~cm}$ below the seafloor. We find an attenuation ranging between $1 \mathrm{~dB} \mathrm{~m}^{-1}$ and $3 \mathrm{~dB} \mathrm{~m}^{-1}$ in our data depth interval $(20-125 \mathrm{~cm})$. This value is consistent with the type of sediments overlying the mud breccia deposits. Using chronostratigraphic markers and sedimentation rate, all detected mud flows are younger than 37,000 60,000 years. We tentatively constrain the episodicity of mud eruption between 50 years and 100 years.
At regional and local scales, there is a clear link between the main active faults and mud expulsion. Shear partitioning activates dextral strike-slip faults at the wedge backstop contact. Whatever the mechanism of expulsion, these faults act as preferential pathways for mud expulsion, especially at fault tips and intersections, or more generally in the zones of fault interactions (releasing and restraining bends).

Based on the kinematics of the wedge, we find it very unlikely that the source of mud volcanism is a layer transported from the trench. We rather suggest in situ production close to the wedge-backstop contact. We show that deep Messinian basins existed close to this boundary prior to the salinity crisis as forearc basins. Messinian mud was deposited in these basins and sealed by the Messinian evaporites. These basins were later inverted in post-Messinian times. This reservoir model does not require refilling, since we calculate that the amount of mud to be mobilized is modest.

We propose to link basin inversion and initiation of mud volcanism to the latest kinematic re-organisations in the area. The present-day rapid rate of convergence $(>3 \mathrm{~cm} /$ year) is the result of the recent motion of the AnatoliaAegean block, which probably took place after 5 m.y., thus triggering large-scale transcurrent motion along the Western and Eastern branches of the Mediterranean Ridge. Opening of the Corinth Gulf, activation of the Kephalonia Fault, change in the stress pattern along the Hellenic arc, indicate that the present-day framework was already established by $1 \mathrm{Ma}$. We relate initiation of mud volcanism to these recent tectonic changes.

Acknowledgements The authors wish to thank three anonymous reviewers for their thorough and constructive comments. We warmly thank J. Ashi for his careful reading of a preliminary version of the manuscript, and P. Clift for his editorial and scientific contribution.

\section{Appendix}

\section{A. Image analysis}

The image analysis starts with the raw image, without grid and coordinates. All images are 8-bits (256 gray levels) grayscale bit-maps. The flow chart of image processing is (1) Remove the lower part of the 256-levels of gray histogram (0-127), considered as noise level; then stretch the resulting histogram to fill the 256 gray levels; (2) Apply a median filter $(3 \times 3$ neighbourhood) to remove spikes; (3) Apply a 192-mask image on the filtered image with a bit-to-bit AND logical operator. This single operation gives the 192 value to all pixels between 192 and 255, the 128 value to all pixels between 128 and 192, the 64 value to all pixels between 64 and 128, and 
the null value to all pixels between 0 and 64; (4) Keep bin 128 as the medium reflectivity and bin 192 as the high reflectivity. This operation allows to keep the pixels between 192 and 256 of the original raw reflectivity image; (5) Remove the slopes (Fig. 3b) above $10^{\circ}(18 \%)$. The slopes have been calculated from the same digital elevation model which produced the bathymetry contoured at $20 \mathrm{~m}$; (6) Perform an open process (erosion operation, followed by dilation, which smoothes objects and removes isolated pixels).

\section{B. Computation of mud volumes}

Reflectivity mapping allowed us to estimate the surface covered by mud flows, over the outer and inner belts. We showed that $92 \%$ of the surface belong to the inner belt, while the remaining $8 \%$ are scattered within the outer belt. We now wish to convert our surface estimates to volumetric estimates. In most cases, the area of the mud flow that we detected is comparable to the size of the corresponding mud volcano. Since we only seek orders of magnitude here, we assume in the following that mud flows can be taken as a proxy for the finite size of the edifice, although we are aware that it may be a rather crude approximation. Each root of the mud volcano is assumed to be a cone. For volumetric calculations, we neglect the relief that stands above the seafloor since most of the volume is within the root itself. We further assume that all volcanoes are homothetic in shape:

$\frac{r}{h}=$ constant

where $r$ is the radius of the cone, and $h$ its height. We define a shape ratio $\lambda$ :

$\lambda=\frac{v}{s}$,

where $v$ is the volume of the root, and $s$ the area of the mud volcano at the seafloor. $\lambda$ is not constant. The cone approximation thus leads to:

$\lambda=\frac{v}{s}=\frac{h}{3}$.

Under the homothetic assumption, we thus have

$\frac{\lambda}{r}=$ constant $=\lambda \sqrt{\pi} s^{-\frac{1}{2}}$,

which implies $\lambda s^{-\frac{1}{2}}=$ constant.

This dimensionless constant characterizes the geometric properties of the entire population. The total volume is:

$V_{T}=\sum_{i} \lambda_{i} s_{i}=\sum_{i}\left(\lambda_{i} s_{i}^{-\frac{1}{2}}\right) s_{i}^{\frac{3}{2}}$

where the summation is over the entire population. Since

$\lambda_{i} s_{i}^{-\frac{1}{2}}=$ constant

the total volume can be rewritten:

$V_{T}=\lambda_{j} s_{j}^{-\frac{1}{2}} \sum_{i} s_{i}^{\frac{3}{2}}$

where subscript $j$ refers to any mud volcano of the population. In other words, if we know the geometric properties of one volcano, the homothetic assumption implies that the total volume can be calculated from the summation of the surfaces.

The Napoli mud volcano, surveyed during ODP Leg 160 (Emeis et al. 1996) was chosen as the reference mud volcano. Applying the previous scheme leads to $\lambda_{j} s_{j}^{-\frac{1}{2}}=0.11 \pm 0.01$. We finally find that for the inner domain, $92 \%$ of the total surface convert to $96 \%$ of the total volume.

\section{Acoustical model}

The standard acoustical propagation law can be written (Mitchell 1993):

$S_{b}=S_{b}(\theta) T_{\mathrm{ws}}^{2}(\theta) T_{\mathrm{sw}}^{2}(\theta) \exp \left(-4 \int_{0}^{h} \frac{\alpha_{p}(z)}{\sin \theta} \mathrm{d} z\right)$,

where $S_{b}(\theta)$ is the effective backscatter coefficient of the buried surface, $\theta$ is the grazing angle of the refracted wave, $z$ is the vertical distance measured below the sediment surface. $\alpha_{p}$ is the attenuation expressed in nepers $\mathrm{m}^{-1}$. The conventional model generally assumes that the attenuation $\alpha$ is constant with depth. Then, taking the logarithm of Eq. 11 and multiplying by 10 to convert the variables to decibels, the effective backscattering strength is:

$\mathrm{BS}=\mathrm{BS}_{v}(\theta)+20 \log _{10}\left(T_{\mathrm{ws}} T_{\mathrm{sw}}\right)-\frac{2 \alpha_{\mathrm{dB}} h}{\sin \theta}$,

where $h$ is the sediment thickness. Some authors measured a decreasing attenuation with depth (Gorgas et al. 2002), which comes to solving Eq. 11 for a varying attenuation with depth, $\alpha_{p}(z)=\alpha_{0}+\beta_{p} z . \beta$ is the rate of attenuation in 
$\mathrm{dB} \mathrm{m} \mathrm{m}^{-2}$, and is negative in unconsolidated superficial sediments, as shown by Gorgas et al. (2002). Equation 11 becomes:

$S_{b}=S_{b}(\theta) T_{\mathrm{ws}}^{2}(\theta) T_{\mathrm{sw}}^{2}(\theta) \exp \left(\frac{-4 \alpha_{0} h}{2 \sin \theta}\right) \exp \left(\frac{-4 \beta_{p} h^{2}}{2 \sin \theta}\right)$

The new expression of BS is:

$\mathrm{BS}=\mathrm{BS}_{v}(\theta)+20 \log _{10}\left(T_{\mathrm{ws}} T_{\mathrm{sw}}\right)-\frac{2 \alpha_{0, \mathrm{~dB}} h}{\sin \theta}-\frac{\beta_{\mathrm{dB}} h^{2}}{\sin \theta}$.

We solve Eq. 14 for the linear case $(\beta=0)$ and for the non-linear case $(\beta<0)$. In the linear case (Eq. 12), the loss is proportional to the effective thickness $h_{e}=h / \sin \theta$, equivalent to the distance traveled by the ray into the sediments. The best linear fit gives $\alpha=2.0 \pm 0.7 \mathrm{~dB} \mathrm{~m}^{-1}$, which is equivalent to $k=0.16 \pm 0.06 \mathrm{~dB} \mathrm{~m}^{-1} \mathrm{kHz}^{-1}$. These values are in the range of values found in-situ by Gorgas et al. (2002) for unconsolidated superficial sediments. In the non-linear case, the best fit gives $\alpha_{0}=3 \mathrm{~dB} \mathrm{~m}^{-1}$ and $\beta=-1.2 \mathrm{~dB} \mathrm{~m}^{-2}$. At a depth of $1 \mathrm{~m}$, $\alpha=1.8 \mathrm{~dB} \mathrm{~m}^{-1}$. The non-linear model does not improve significantly the fit, and although plausible, the decrease of the attenuation with depth is not required by our data. In any case, both models lead to the same range of values for the attenuation.

D. Characteristics of inferred mud flows

In Table 3 are given some characteristics of the mud flows identified on the Mediterranean Ridge during the course of the present study.

Table 3 Longitude, latitude and depth of inferred emission point, associated mud flows surface, for the 215 mud flows individualized over the western Mediterranean Ridge, sorted according to decreasing latitude. mbsl is metres below sea level

\begin{tabular}{|c|c|c|c|c|c|c|c|c|c|}
\hline $\begin{array}{l}\text { Longitude } \\
\text { (d:m:s) }\end{array}$ & $\begin{array}{l}\text { Latitude } \\
\text { (d:m:s) }\end{array}$ & $\begin{array}{l}\text { Surface } \\
\left(\mathrm{km}^{2}\right)\end{array}$ & $\begin{array}{l}\text { Depth } \\
\text { (mbsl) }\end{array}$ & Name & $\begin{array}{l}\text { Longitude } \\
\text { (d:m:s) }\end{array}$ & $\begin{array}{l}\text { Latitude } \\
\text { (d:m:s) }\end{array}$ & $\begin{array}{l}\text { Surface } \\
\left(\mathrm{km}^{2}\right)\end{array}$ & $\begin{array}{l}\text { Depth } \\
\text { (mbsl) }\end{array}$ & Name \\
\hline 19:37:11 & $37: 56: 28$ & 3.45 & 3,337 & - & $20: 43: 41$ & $36: 22: 19$ & 5.61 & 2,848 & - \\
\hline $19: 37: 3$ & $37: 50: 6$ & 3.71 & 3,310 & - & $20: 47: 12$ & $36: 22: 12$ & 2.77 & 2,830 & - \\
\hline 19:49:58 & $37: 49: 57$ & 2.67 & 3,451 & - & 20:44:19 & $36: 21: 40$ & 0.87 & 2,846 & - \\
\hline 19:45:16 & $37: 43: 41$ & 0.60 & 3,306 & - & $20: 46: 2$ & $36: 20: 43$ & 8.59 & 2,856 & - \\
\hline 19:46:16 & $37: 28: 28$ & 1.30 & 3,335 & - & $20: 47: 23$ & 36:19:59 & 4.17 & 2,912 & - \\
\hline $19: 25: 2$ & $37: 25: 29$ & 1.98 & 3,390 & - & $20: 36: 25$ & $36: 19: 41$ & 5.28 & 2,797 & - \\
\hline $19: 40: 5$ & $37: 21: 45$ & 1.48 & 3,507 & - & $20: 49: 25$ & $36: 19: 35$ & 4.24 & 2,943 & - \\
\hline $19: 55: 21$ & $37: 21: 35$ & 5.72 & 3,284 & - & $20: 55: 39$ & $36: 18: 40$ & 2.00 & 3,633 & - \\
\hline 19:58:39 & $37: 20: 17$ & 7.67 & 3,210 & - & $20: 35: 22$ & $36: 18: 38$ & 14.72 & 2,807 & - \\
\hline $19: 45: 35$ & $37: 18: 42$ & 2.11 & 3,496 & - & $20: 44: 5$ & $36: 16: 42$ & 1.21 & 2,983 & - \\
\hline $19: 57: 25$ & $37: 14: 19$ & 39.36 & 3,198 & - & $20: 40: 7$ & $36: 15: 49$ & 1.50 & 2,779 & - \\
\hline $20: 3: 58$ & $37: 9: 15$ & 20.91 & 3,106 & - & $20: 46: 16$ & $36: 15: 14$ & 0.79 & 2,957 & - \\
\hline $18: 57: 7$ & $37: 9: 12$ & 1.84 & 3,420 & - & $20: 44: 49$ & $36: 14: 58$ & 7.22 & 2,895 & - \\
\hline $19: 32: 54$ & $37: 6: 22$ & 2.69 & 3,381 & - & $20: 47: 26$ & 36:11:39 & 5.45 & 2,870 & - \\
\hline $20: 9: 2$ & $37: 5: 56$ & 14.80 & 2,991 & - & $20: 24: 59$ & $36: 10: 50$ & 3.24 & 3,118 & - \\
\hline $19: 51: 17$ & $37: 0: 42$ & 18.08 & 3,522 & - & $20: 46: 7$ & $36: 10: 39$ & 8.46 & 2,752 & - \\
\hline $19: 46: 48$ & $36: 58: 8$ & 7.21 & 3,522 & - & $20: 41: 4$ & $36: 10: 2$ & 7.20 & 2,950 & - \\
\hline $20: 27: 12$ & $36: 51: 50$ & 3.21 & 3,202 & - & $20: 48: 36$ & $36: 6: 55$ & 18.66 & 2,632 & - \\
\hline $19: 52: 25$ & $36: 50: 15$ & 0.88 & 3,195 & - & $20: 58: 17$ & $36: 6: 37$ & 4.98 & 3,423 & - \\
\hline $20: 31: 13$ & $36: 50: 2$ & 3.32 & 3,426 & - & $21: 1: 48$ & $36: 5: 18$ & 1.35 & 3,553 & - \\
\hline $19: 49: 12$ & $36: 49: 51$ & 1.80 & 3,311 & - & $20: 49: 44$ & $36: 4: 30$ & 2.04 & 2,751 & - \\
\hline $19: 44: 25$ & $36: 46: 37$ & 1.43 & 3,227 & - & $20: 50: 47$ & $36: 4: 21$ & 16.34 & 2,753 & - \\
\hline 19:55:7 & $36: 46: 22$ & 2.35 & 3,243 & - & $20: 48: 47$ & $36: 3: 30$ & 4.33 & 2,795 & - \\
\hline $20: 33: 53$ & $36: 46: 9$ & 28.30 & 2,894 & - & $20: 53: 21$ & $36: 3: 28$ & 3.67 & 2,925 & - \\
\hline $19: 45: 24$ & $36: 43: 28$ & 1.37 & 3,187 & - & $20: 46: 21$ & $36: 2: 29$ & 3.87 & 2,863 & - \\
\hline $20: 21: 0$ & $36: 40: 10$ & 2.64 & 2,901 & - & $20: 48: 12$ & $36: 2: 22$ & 2.55 & 2,803 & - \\
\hline $20: 29: 54$ & $36: 38: 7$ & 1.34 & 2,767 & - & $20: 50: 36$ & $36: 2: 18$ & 3.81 & 2,889 & - \\
\hline 19:56:1 & $36: 37: 52$ & 1.04 & 3,102 & - & 20:56:17 & $36: 1: 40$ & 38.11 & 2,792 & - \\
\hline
\end{tabular}


Table 3 continued

\begin{tabular}{|c|c|c|c|c|c|c|c|c|c|}
\hline $\begin{array}{l}\text { Longitude } \\
\text { (d:m:s) }\end{array}$ & $\begin{array}{l}\text { Latitude } \\
\text { (d:m:s) }\end{array}$ & $\begin{array}{l}\text { Surface } \\
\left(\mathrm{km}^{2}\right)\end{array}$ & $\begin{array}{l}\text { Depth } \\
\text { (mbsl) }\end{array}$ & Name & $\begin{array}{l}\text { Longitude } \\
\text { (d:m:s) }\end{array}$ & $\begin{array}{l}\text { Latitude } \\
\text { (d:m:s) }\end{array}$ & $\begin{array}{l}\text { Surface } \\
\left(\mathrm{km}^{2}\right)\end{array}$ & $\begin{array}{l}\text { Depth } \\
\text { (mbsl) }\end{array}$ & Name \\
\hline $20: 23: 51$ & $36: 35: 50$ & 2.48 & 2,881 & - & $20: 51: 25$ & $36: 1: 14$ & 5.45 & 2,925 & Aros \\
\hline $20: 42: 3$ & $36: 35: 17$ & 2.44 & 2,845 & - & $21: 2: 1$ & $35: 59: 17$ & 5.37 & 3,125 & - \\
\hline $20: 34: 17$ & $36: 33: 39$ & 15.89 & 2,963 & - & $20: 52: 30$ & $35: 58: 49$ & 4.43 & 2,871 & - \\
\hline $20: 40: 37$ & $36: 32: 14$ & 8.87 & 2,846 & - & $20: 54: 13$ & $35: 58: 40$ & 1.98 & 2,907 & - \\
\hline $20: 55: 53$ & $36: 28: 22$ & 2.84 & 3,390 & - & $20: 47: 15$ & $35: 58: 31$ & 2.54 & 2,864 & - \\
\hline $20: 48: 50$ & $36: 28: 16$ & 5.43 & 3,020 & - & $20: 44: 43$ & $35: 58: 11$ & 9.38 & 2,765 & - \\
\hline $20: 46: 2$ & $36: 24: 46$ & 14.24 & 2,884 & - & $21: 2: 53$ & $35: 58: 0$ & 8.21 & 3,010 & - \\
\hline $20: 42: 58$ & $36: 23: 40$ & 19.03 & 2,800 & - & 21:0:51 & $35: 57: 23$ & 5.10 & 2,993 & - \\
\hline $20: 53: 21$ & $35: 57: 5$ & 2.02 & 2,891 & - & $20: 4: 50$ & $35: 30: 59$ & 1.20 & 3,049 & - \\
\hline $20: 46: 24$ & $35: 56: 52$ & 5.02 & 2,842 & - & $20: 53: 24$ & $35: 28: 41$ & 14.25 & 2,925 & - \\
\hline $21: 2: 53$ & $35: 56: 21$ & 4.41 & 3,066 & - & 21:9:26 & $35: 28: 23$ & 3.97 & 2,970 & - \\
\hline $21: 1: 43$ & $35: 55: 59$ & 2.75 & 2,976 & - & $20: 43: 6$ & $35: 28: 21$ & 6.03 & 3,032 & - \\
\hline $20: 52: 49$ & $35: 55: 35$ & 12.25 & 2,879 & Nov. & $20: 8: 43$ & $35: 28: 8$ & 0.86 & 3,022 & - \\
\hline $21: 2: 26$ & $35: 54: 55$ & 3.04 & 3,007 & - & $20: 39: 26$ & $35: 27: 21$ & 3.24 & 3,001 & - \\
\hline $21: 4: 39$ & $35: 54: 24$ & 5.18 & 3,114 & - & $21: 13: 27$ & $35: 25: 50$ & 1.96 & 2,875 & - \\
\hline $21: 3: 17$ & $35: 53: 46$ & 2.90 & 3,011 & - & $20: 9: 26$ & $35: 25: 14$ & 1.03 & 3,032 & - \\
\hline $20: 48: 4$ & $35: 51: 12$ & 7.30 & 2,974 & Prom. & $21: 14: 8$ & $35: 24: 45$ & 3.09 & 2,916 & - \\
\hline $21: 1: 15$ & $35: 51: 7$ & 2.66 & 2,971 & - & $20: 54: 32$ & $35: 24: 39$ & 14.76 & 2,884 & - \\
\hline $20: 55: 9$ & $35: 50: 23$ & 2.58 & 2,965 & - & $21: 2: 1$ & $35: 23: 10$ & 0.44 & 2,922 & - \\
\hline $20: 57: 1$ & $35: 47: 11$ & 0.62 & 2,947 & - & $21: 21: 22$ & $35: 22: 16$ & 5.29 & 3,234 & - \\
\hline $20: 7: 24$ & $35: 46: 58$ & 1.68 & 3,093 & - & $21: 5: 22$ & $35: 19: 16$ & 21.62 & 3,009 & - \\
\hline $20: 49: 12$ & $35: 46: 40$ & 29.00 & 2,850 & - & $20: 7: 49$ & $35: 18: 14$ & 0.82 & 2,988 & - \\
\hline $20: 55: 15$ & $35: 42: 52$ & 0.85 & 2,968 & - & $20: 8: 46$ & $35: 17: 49$ & 0.67 & 3,011 & - \\
\hline $20: 51: 6$ & $35: 41: 28$ & 0.55 & 2,973 & - & $20: 23: 19$ & $35: 16: 58$ & 2.36 & 2,876 & - \\
\hline $21: 2: 42$ & $35: 40: 26$ & 1.62 & 2,845 & - & $21: 27: 38$ & $35: 15: 27$ & 3.45 & 3,414 & - \\
\hline $21: 1: 51$ & $35: 39: 53$ & 0.98 & 2,925 & - & $20: 38: 43$ & $35: 14: 53$ & 1.20 & 3,008 & - \\
\hline $21: 7: 13$ & $35: 39: 40$ & 0.65 & 3,100 & - & $21: 24: 34$ & $35: 14: 15$ & 1.12 & 3,392 & - \\
\hline $21: 4: 52$ & $35: 39: 2$ & 6.13 & 2,957 & - & $21: 4: 39$ & $35: 13: 24$ & 5.02 & 3,049 & - \\
\hline $21: 2: 31$ & $35: 38: 9$ & 2.76 & 2,881 & - & $20: 21: 25$ & $35: 12: 33$ & 1.05 & 2,942 & - \\
\hline $20: 51: 19$ & $35: 38: 7$ & 12.82 & 2,951 & Fig. 11 & $21: 0: 56$ & $35: 12: 2$ & 1.17 & 3,062 & - \\
\hline $20: 4: 42$ & $35: 37: 53$ & 1.97 & 3,071 & - & $21: 2: 18$ & $35: 11: 17$ & 3.14 & 3,064 & - \\
\hline $20: 26: 58$ & $35: 37: 44$ & 1.98 & 3,122 & - & $20: 27: 23$ & $35: 11: 15$ & 1.55 & 2,852 & - \\
\hline $21: 6: 41$ & $35: 37: 36$ & 3.57 & 2,926 & - & $21: 4: 55$ & $35: 10: 37$ & 0.98 & 3,036 & - \\
\hline $20: 35: 22$ & $35: 37: 25$ & 1.21 & 3,068 & - & 20:9:18 & $35: 10: 14$ & 2.78 & 2,891 & - \\
\hline $21: 1: 53$ & $35: 36: 53$ & 3.02 & 2,888 & - & $21: 18: 44$ & $35: 9: 41$ & 13.97 & 2,888 & - \\
\hline 21:9:10 & $35: 36: 25$ & 32.15 & 2,961 & - & $20: 42: 6$ & $35: 9: 37$ & 0.44 & 2,934 & - \\
\hline $21: 2: 50$ & $35: 36: 16$ & 7.92 & 2,873 & - & $20: 27: 33$ & $35: 8: 34$ & 2.66 & 2,833 & - \\
\hline $21: 0: 24$ & $35: 36: 5$ & 3.66 & 2,828 & - & $20: 8: 5$ & $35: 8: 25$ & 1.75 & 2,922 & - \\
\hline $19: 44: 14$ & $35: 35: 56$ & 1.31 & 3,151 & - & $21: 19: 49$ & $35: 6: 22$ & 5.19 & 3,015 & - \\
\hline $20: 19: 12$ & $35: 35: 31$ & 0.93 & 2,989 & - & $20: 44: 38$ & $35: 5: 35$ & 14.18 & 2,681 & - \\
\hline 20:20:6 & $35: 33: 47$ & 2.59 & 2,976 & - & $20: 56: 9$ & $35: 3: 12$ & 2.24 & 2,705 & - \\
\hline $20: 24: 34$ & $35: 33: 5$ & 0.54 & 3107 & - & $20: 29: 33$ & $35: 3: 1$ & 1.22 & 2,843 & - \\
\hline $20: 15: 30$ & $35: 32: 41$ & 1.82 & 2,880 & - & $20: 27: 50$ & $35: 2: 14$ & 3.33 & 2,809 & - \\
\hline $21: 7: 57$ & $35: 32: 1$ & 1.11 & 2,914 & - & 21:6:30 & $35: 1: 59$ & 2.81 & 2,645 & - \\
\hline 21:9:23 & $35: 1: 0$ & 5.42 & 2,626 & - & $22: 8: 2$ & $34: 5: 38$ & 8.49 & 2,251 & - \\
\hline 21:0:16 & $35: 0: 7$ & 1.80 & 2,538 & - & $23: 26: 46$ & $34: 4: 52$ & 36.00 & 2,312 & - \\
\hline $21: 20: 27$ & $35: 0: 0$ & 1.73 & 2,850 & - & $22: 11: 52$ & $34: 2: 2$ & 1.96 & 2,030 & - \\
\hline $20: 59: 35$ & $34: 59: 31$ & 1.83 & 2,569 & - & $22: 14: 16$ & $34: 1: 33$ & 35.29 & 2,016 & - \\
\hline
\end{tabular}


Table 3 continued

\begin{tabular}{|c|c|c|c|c|c|c|c|c|c|}
\hline $\begin{array}{l}\text { Longitude } \\
\text { (d:m:s) }\end{array}$ & $\begin{array}{l}\text { Latitude } \\
\text { (d:m:s) }\end{array}$ & $\begin{array}{l}\text { Surface } \\
\left(\mathrm{km}^{2}\right)\end{array}$ & $\begin{array}{l}\text { Depth } \\
\text { (mbsl) }\end{array}$ & Name & $\begin{array}{l}\text { Longitude } \\
\text { (d:m:s) }\end{array}$ & $\begin{array}{l}\text { Latitude } \\
\text { (d:m:s) }\end{array}$ & $\begin{array}{l}\text { Surface } \\
\left(\mathrm{km}^{2}\right)\end{array}$ & $\begin{array}{l}\text { Depth } \\
\text { (mbsl) }\end{array}$ & Name \\
\hline $21: 19: 22$ & $34: 59: 2$ & 3.83 & 2,783 & - & $22: 16: 37$ & 33:59:44 & 0.93 & 2,053 & - \\
\hline $21: 20: 33$ & $34: 58: 37$ & 5.40 & 2768 & - & $21: 55: 25$ & $33: 58: 38$ & 8.13 & 2,019 & - \\
\hline $21: 21: 3$ & $34: 56: 25$ & 1.74 & 2,737 & - & $22: 19: 35$ & $33: 58: 24$ & 7.34 & 2,147 & - \\
\hline $20: 16: 16$ & $34: 56: 21$ & 0.55 & 2,932 & - & $22: 7: 53$ & $33: 57: 41$ & 12.01 & 2,191 & - \\
\hline $20: 51: 14$ & $34: 55: 54$ & 2.22 & 2,748 & - & $23: 21: 48$ & $33: 57: 21$ & 2.35 & 2,079 & - \\
\hline $20: 45: 27$ & $34: 54: 22$ & 3.34 & 2,801 & - & $22: 47: 33$ & $33: 56: 13$ & 78.43 & 1,847 & - \\
\hline $20: 19: 12$ & $34: 54: 6$ & 1.89 & 2,845 & - & $22: 51: 5$ & $33: 56: 1$ & 26.52 & 1,847 & - \\
\hline $20: 4: 45$ & $34: 51: 47$ & 3.63 & 2,882 & - & $23: 6: 34$ & $33: 55: 41$ & 19.03 & 1,968 & - \\
\hline $20: 4: 55$ & $34: 50: 27$ & 3.23 & 2,903 & - & $22: 1: 7$ & $33: 51: 20$ & 9.21 & 2,076 & - \\
\hline $20: 23: 27$ & $34: 50: 11$ & 1.33 & 2,815 & - & $23: 19: 11$ & $33: 50: 46$ & 4.07 & 1,717 & - \\
\hline $20: 41: 28$ & $34: 49: 31$ & 3.08 & 2,689 & - & $23: 18: 57$ & $33: 50: 5$ & 7.31 & 1,688 & - \\
\hline 20:19:1 & $34: 49: 13$ & 1.62 & 2,853 & - & $20: 36: 41$ & $33: 48: 31$ & 0.72 & 2,722 & - \\
\hline $21: 6: 46$ & $34: 48: 44$ & 4.50 & 2,350 & - & $21: 54: 23$ & $33: 48: 4$ & 1.37 & 2,047 & - \\
\hline $21: 24: 53$ & $34: 48: 3$ & 5.59 & 2,448 & - & $22: 25: 20$ & $33: 47: 14$ & 32.81 & 1,365 & - \\
\hline $21: 36: 19$ & $34: 44: 48$ & 1.95 & 2,567 & - & $21: 54: 4$ & $33: 46: 54$ & 2.96 & 2,042 & - \\
\hline $21: 23: 24$ & $34: 42: 15$ & 2.61 & 2,212 & - & $22: 14: 51$ & $33: 46: 51$ & 7.01 & 1,853 & - \\
\hline $20: 22: 24$ & $34: 42: 4$ & 3.15 & 2,802 & - & $22: 32: 12$ & $33: 46: 10$ & 2.67 & 1,433 & - \\
\hline $20: 30: 32$ & $34: 41: 59$ & 4.69 & 2,719 & - & $22: 9: 23$ & $33: 46: 8$ & 67.20 & 1,709 & - \\
\hline $21: 57: 38$ & $34: 41: 24$ & 3.73 & 2,825 & - & $20: 31: 32$ & $33: 46: 1$ & 0.99 & 2,855 & - \\
\hline $21: 58: 13$ & $34: 39: 11$ & 1.49 & 2,319 & - & $22: 42: 49$ & $33: 46: 1$ & 43.04 & 1,158 & Anteus \\
\hline $21: 54: 4$ & $34: 38: 55$ & 1.26 & 2,205 & - & $23: 13: 24$ & $33: 44: 39$ & 5.80 & 1,497 & - \\
\hline $21: 21: 51$ & $34: 38: 15$ & 3.17 & 2,234 & - & $22: 16: 1$ & $33: 44: 10$ & 11.47 & 1,843 & - \\
\hline $21: 59: 32$ & $34: 38: 10$ & 0.51 & 2,327 & - & $22: 48: 11$ & $33: 44: 10$ & 13.54 & 1,385 & - \\
\hline $21: 47: 47$ & $34: 34: 36$ & 2.16 & 2,227 & - & $22: 13: 24$ & $33: 42: 57$ & 3.44 & 1,796 & - \\
\hline $21: 41: 6$ & $34: 28: 0$ & 2.18 & 2,334 & - & $23: 12: 46$ & $33: 32: 37$ & 1.39 & 1,966 & - \\
\hline $21: 35: 41$ & $34: 25: 29$ & 5.99 & 2,126 & - & $22: 21: 21$ & $33: 29: 39$ & 1.71 & 1,699 & - \\
\hline $22: 10: 55$ & $34: 24: 3$ & 76.01 & 2,145 & - & $22: 5: 24$ & $33: 28: 30$ & 1.04 & 1,930 & - \\
\hline $20: 42: 58$ & $34: 22: 47$ & 0.97 & 2,587 & - & $20: 54: 37$ & $33: 24: 28$ & 3.04 & 3,008 & - \\
\hline $22: 8: 29$ & $34: 13: 58$ & 10.12 & 2,397 & - & $22: 3: 17$ & $33: 20: 23$ & 9.26 & 2,181 & - \\
\hline 21:51:59 & $34: 7: 54$ & 18.50 & 2,203 & - & $22: 21: 46$ & $33: 19: 33$ & 2.47 & 2,247 & - \\
\hline $23: 26: 13$ & $34: 6: 46$ & 5.90 & 2,418 & - & $21: 11: 20$ & $33: 15: 21$ & 4.14 & 2,920 & - \\
\hline $22: 34: 22$ & $34: 5: 38$ & 1.79 & 2,301 & - & & & & & \\
\hline
\end{tabular}

Names of known mud volcanoes: Nov, Novorossiysk; Prom, Prometheus

\section{References}

Akhmanov G (1996) Lithology of mud breccia clasts from the Mediterranean Ridge. Mar Geol 132(1-4):151-164

Akhmanov GG, Woodside JM (1998) Mud volcanic samples in the context of the Mediterranean Ridge mud diapiric belt. In: Robertson AHF, Emeis K-C, Richter C, Camerlenghi A (eds) Proc ODP, vol 160. Scientific Results (Ocean Drilling Program), College Station, TX, pp 597-605

Akhmanov GG, Premoli Silva I, Erba E, Cita MB (2003) Sedimentary succession and evolution of the Mediterranean Ridge western sector as derived from lithology of mud breccia clasts. Mar Geol 195:277-299

Aloisi G, Pierre C, Rouchy J-M, Foucher J-P, Woodside J, The MEDINAUT Scientific Party (2000) Methane-related authigenic carbonates of eastern Mediterranean Sea mud volcanoes and their possible relation to gas hydrate destabilisation. Earth Planet Sci Lett 184(1):321-338

Armijo R, Meyer B, Hubert A, Barka A (1999) Westward propagation of the North Anatolian fault into the northern Aegean: timing and kinematics. Geology 27(3):267-270

Breen N, Silver E, Hussong D (1986) Structural styles of an accretionary wedge south of the island of Sumba, Indonesia, revealed by SeaMARC II side scan sonar. Geol Soc Am Bull 97:1250-1261

Breen N, Silver E, Roof S (1989) The Water back arc thrust belt, Eastern Indonesia: the effect of accretion against an irregularly shaped arc. Tectonics 8(1):85-98

Brown K, Westbrook G (1988) Mud diapirism and subcretion in the Barbados Ridge accretionary complex; the role of fluids in accretionary processes. Tectonics 7(3):613-640 
Calais E, DeMets C, Nocquet J (2003) Evidence for a post-3.16-Ma change in Nubia Eurasia North America plate motions? Earth Planet Sci Lett 216(1-2):81-92

Camerlenghi A, Cita M, Hieke W, Ricchiuto T (1992) Geological evidence for mud diapirism on the Mediterranean Ridge accretionary complex. Earth Planet Sci Lett 109(3-4):493-504

Camerlenghi A, Cita M, Della Vedova B, Fusi N, Mirabile L, Pellis G (1995) Geophysical evidence of mud diapirism on the Mediterranean Ridge accretionary complex. Mar Geophys Res 17(2):115-141

Camerlenghi A, Pini GA (2007) Mud volcanoes, olistostromes, and argille scagliose in the Mediterranean Region. In: McKenzie JA, Bernoulli D, Cita MB (eds) Major discoveries in sedimentary geology in the Mediterranean realm from a historical perspective to new developments. IAS Special Publications, Blackwell Publishing, in press

Ceramicola S, Praeg D, Monteys X, Unnithan V, Wardell N, Cova A, Garziglia S, OGS Explora Scientific Party (2006) Imaging of a new province of seabed cold seeps in the northern Ionian Sea (Calabrian Arc) - towards ecosystems mapping. In: Geophysics Research Abstracts, vol 8, p 4868

Chamot-Rooke N, Rabaute A, Kreemer C (2005a) Western Mediterranean Ridge mud belt correlates with active shear strain at the prism-backstop geological contact. Geology 33(11):861-864

Chamot-Rooke N, Rangin C, Le Pichon X, Rabaute A, Laurent O, Ego F, Lallemant S, Nielsen C, Pagot P, Tsang Hin Sun D, Walcott R, Bousquet R (2005b) DOTMED: a synthesis of deep marine data in eastern Mediterranean. Mém. Soc. Géol. France 177:64, 9 pl. + cdrom

Chaumillon E, Mascle J, Hoffmann J (1996) Deformation of the western Mediterranean Ridge; importance of Messinian evaporitic formations. Tectonophysics 263(1-4):163-190

Cita M, Ryan W, Paggi L (1981) Prometheus mud breccia; an example of shale diapirism in the Western Mediterranean Ridge. Annales Géologiques des Pays Helléniques 30:543-570

Cita M, Bossio A, Colombo A, Gnaccolinia M, Salvatorini G, Kastens K, McCoy F, Broglia C, Camerlenghi A, Catrullo D, Clauzon G, Croce M, Giambastiani M, Malinverno A, Parisi E (1982) Stratigraphy and neotectonics in the eastern Mediterranean Ridge; Cobblestone area 3 re-visited. Mem Soc Geol It 24(Part 2):443-458

Costa E, Camerlenghi A, Polonia A, Cooper C, Fabretti P, Mosconi A, Murelli P, Romanelli M, Sormani L, Wardell N (2004) Modeling deformation and salt tectonics in the eastern Mediterranean Ridge accretionary wedge. Geol Soc Am Bull 116(7/ 8):880-894

Cronin BT, Ivanov MK, Limonov AF, Egorov A, Akhmanov GG, Akhmetjanov AM, Kozlova E, Shipboard, Scientific Party TTR5 (1997) New discoveries of mud volcanoes on the Eastern Mediterranean Ridge. J Geol Soc London 154:173-182

Curewitz D, Karson J (1997) Structural settings of hydrothermal outflow: fracture permeability maintained by fault propagation and interaction. J Volcanol Geotherm Res 79(3-4):149-168

Emeis K-C, Robertson A, Richter C et al (eds) (1996) Proc ODP, vol 160. Init Repts, (Ocean Drilling Program) College Station, TX

Flotte N, Plagnes V, Sorel D, Benedicto A (2001) Attempt to date Pleistocene normal faults of the Corinth-Patras Rift (Greece) by U/Th method, and tectonic implications. Geophys Res Lett 28(19):3769-3772

Fruehn J, Reston T, von Huene R, Bialas J (2002) Structure of the Mediterranean Ridge accretionary complex from seismic velocity information. Mar Geol 186(1-2):43-58

Fusi N, Kenyon N (1996) Distribution of mud diapirism and other geological structures from long-range sidescan sonar (GLORIA) data, in the eastern Mediterranean Sea. Mar Geol 132(1-4):21-38
Galindo-Zaldivar J, Nieto L, Woodside J (1996) Structural features of mud volcanoes and the fold system of the Mediterranean Ridge, south of Crete. Mar Geol 132(1-4):95-112

Gorgas T, Wilkens R, Fu S, Frazer N, Richardson M, Briggs K, Lee H (2002) In situ acoustic and laboratory ultrasonic sound speed and attenuation measured in hetegeneous soft seabed sediments: Eel River shelf California. Mar Geol 182(1-2):103-119

Hamilton EL (1972) Compressional wave attenuation in marine sediments. Geophysics 37:620-646

Hamilton EL (1980) Geoacoustic modeling of the sea floor. J Acoust Soc Am 68(5):1313-1340

Henry P, Le Pichon X, Lallemant S, Foucher J-P (1990) Mud volcano field seaward of the Barbados accretionary complex; a deeptowed scan sonar. J Geophys Res B 95(6):8917-8929

Hensen C, Nuzzo M, Hornibrook E, Pinheiro LM, Bock B, Magalhaes VH, Bruckmann W (2007) Sources of mud volcano fluids in the Gulf of Cadiz-indications for hydrothermal imprint. Geochim Cosmochim Acta 71(5):1232-1248

Hieke W, Cita M, Mirabile G, Negri A, Werner F (1996) The summit area (Antaeus/Pan di Zucchero) of the Mediterranean Ridge; a mud diapir field?. Mar Geol 132(1-4):113-129

Hubert-Ferrari A, Armijo R, King G, Meyer B, Barka A (2002) Morphology, displacement, and slip rates along the North Anatolian Fault. J Geophys Res 107(B10), doi:10.1029/ 2001JB000,393

Huguen C (2001) Déformation récente à actuelle et argilo-cinèse associée au sein de la Ride Méditerranéenne (Méditerranée orientale). Ph.D. thesis, Université Pierre et Marie Curie, Paris VI

Huguen C, Mascle J, Chaumillon E, Kopf A, Woodside J, Zitter T (2004) Structural setting and tectonic control of mud volcanoes from the Central Mediterranean Ridge (Eastern Mediterranean). Mar Geol 209(1-4):245-263, doi:10.1016/j.margeo.2004.05.002

Huguen C, Mascle J, Woodside J, Zitter T, Foucher J-P (2005) Mud volcanoes and mud domes of the Central Mediterranean Ridge: near-bottom and in situ observations. Deep Sea Res. Part IOceanogr Res Papers 52(10):1911-1931

Huguen C, Chamot-Rooke N, Loubrieu B, Mascle J (2006) Morphology of a pre-collisional, salt-bearing, accretionary complex: the Mediterranean Ridge (Eastern Mediterranean). Mar Geophys Res 27(1):61-75

Ivanov M, Limonov A, Cronin B (1996a) Mud volcanism and fluid venting in the eastern part of the Mediterranean Ridge, vol 68. UNESCO Rep. Mar. Sci., Paris

Ivanov M, Limonov A, van Weering T (1996b) Comparative characteristics of the Black Sea and Mediterranean Ridge mud volcanoes. Mar Geol 132(1-4):253-271

Jackson DR, Winebrenner DP, Ishimaru A (1986) Application of the composite roughness model to high-frequency bottom backscattering. J Acoust Soc Am 79(5):1410-1422

Kastens K (1991) Rate of outward growth of the Mediterranean Ridge accretionary complex. Tectonophysics 199:25-50

Kobayashi K, Ashi J, Boulégue J, Cambray H, Chamot-Rooke N, Fujimoto $\mathrm{H}$, Furuta $\mathrm{T}$, Iiyama J, Koizumi T, Mitsuzawa $\mathrm{K}$, Monma H, Murayama M, Naka J, Nakanishi M, Ogawa Y, Otsuka K, Okada M, Oshida A, Shima N, Soh W, Takeushi A, Watanabe M, Yamagata T (1992) Deep-tow survey in the KAIKO-Nankai cold seepage areas. Earth Planet Sci Lett 109:347-354

Kopf A (1999) Fate of sediment during plate convergence at the Mediterranean Ridge accretionary complex; volume balance of mud extrusion versus subduction and/or accretion. Geology 27(1):87-90

Kopf A (2002) Significance of mud volcanism. Rev Geophys 40(2):1-52

Kopf A, Behrmann J (2000) Extrusion dynamics of mud volcanoes on the Mediterranean Ridge accretionary complex. In: Vendeville 
B, Mart Y, Vigneresse J (eds) Salt, shales and igneous diapirs in and around Europe, vol 174. Geological Society Special Publications, London, pp 169-204

Kopf A, Robertson A, Volkmann N (2000) Origin of mud breccia from the Mediterranean Ridge accretionary complex based on evidence of the maturity of organic matter and related petrographic and regional tectonic evidence. Mar Geol 166 $(1-4): 65-82$

Kopf A, Klaeschen D, Mascle J (2001) Extreme efficiency of mud volcanism in dewatering accretionary prisms. Earth Planet Sci Lett 189(3-4):295-313

Kreemer C, Chamot-Rooke N (2004) Contemporary kinematics of the southern Aegean and the Mediterranean Ridge. Geophys J Int 157(3):1377-1392

Kroon D, Alexander I, Little M, Lourens L, Matthewson A, Robertson A, Sakamoto T (1998) Oxygen isotope and sapropel stratigraphy in the eastern mediterranean during the last 3.2 million years, vol 160. In: Robertson AHF, Emeis K-C, Richter C, Camerlenghi A (eds) Proc ODP. Scientific Results (Ocean Drilling Program), College Station, TX, pp 181-189

Le Pichon X, Henry P, Lallemant S, Foucher J-P, Boulegue J, Westbrook G, Avedik F, Langseth M, Hobart M, Benedetti M (1990) Mud volcano field seaward of the Barbados accretionary complex; a submersible survey. J Geophys Res B 95(6): 8931-8943

Le Pichon X, Chamot-Rooke N, Lallemant S, Noomen R, Veis G (1995) Geodetic determination of the kinematics of Central Greece with respect to Europe-implications for Eastern Mediterranean tectonics. J Geophys Res B 100(7): $12675-12690$

Le Pichon X, Lallemant S, Chamot-Rooke N, Lemeur D, Pascal G (2002) The Mediterranean Ridge backstop and the Hellenic nappes. Mar Geol 186(1-2):111-125

Limonov A, Kenyon N, Ivanov M, Woodside J (1995) Deep-sea depositional systems of the Western Mediterranean and mud volcanism on the Mediterranean Ridge, vol 67. UNESCO Rep. Mar. Sci., Paris

Limonov A, Woodside J, Cita M, Ivanov M (1996) The Mediterranean Ridge and related mud diapirism; a background. Mar Geol 132(1-4):7-19

Loncke L, Mascle J, FANIL Scientific Parties (2004) Mud volcanoes, gas chimneys, pockmarks and mounds in the Nile deep-sea fan (Eastern Mediterranean): geophysical evidences. Mar Pet Geol 21:669-689

McCluky S, Reilinger R, Mahmoud S, Ben Sari D, Tealeb A (2003) GPS constraints on Africa (Nubia) and Arabia plate. Geophys J Int 155(1):126-138

McKenzie D (1972) Active tectonics of the Mediterranean region. Geophys J R Astron Soc 30:109-185

MEDINAUT/MEDINETH Scientific Party (2000) Linking Mediterranean brine pools and mud volcanism. Eos Trans AGU 81(51):625, 631-632

Mellors R, Kilb D, Aliyev A, Gasanov A, Yetirmishli G (2007) Correlations between earthquakes and large mud volcano eruptions. J Geophys Res 112:B04304, doi:10.1029/ 2006JB004489

Mercier J, Sorel D, Simeakis K (1987) Changes in the state of stress in the overriding plate of a subduction zone: the Aegean arc from the Pliocene to the present. Ann Tectonicae 1:20-39

Mitchell N (1993) A model for attenuation of backscatter due to sediment accumulations and its application to determine sediment thickness with GLORIA sidescan sonar. J Geophys Res B 98(12):22477-22493

Netzeband GL, Hübscher CP, Gajewski D (2006) The structural evolution of the Messinian evaporites in the Levantine Basin. Mar Geol 230:249-273
Nielsen C, Rangin C, Chamot-Rooke N, Sorel D, Laurent O (2001) The occidental termination of the Mediterranean Ridge: onshore and offshore constraints along the Kephalonia Fault. In: Geophysics Research Abstracts, vol 3, March 2001, France, p 872

Nielsen C, Chamot-Rooke N, Rangin C, Andaman Cruise Team (2004) From partial to full strain partitioning along the IndoBurmese hyper-oblique subduction. Mar Geol 209(1-4):303327, doi:10.1016/j.margeo.2004.05.001

Pérez Belzuz F, Alonso B, Ercilla G (1997) History of mud diapirism and trigger mechanisms in the western Alboran Sea. Tectonophysics 282(1-4):399-422

Piper D, Perissoratis C (2003) Quaternary neotectonics of the South Aegean arc. Mar Geol 198(3-4):259-288

Reston T, Fruehn J, von Huene R (2002a) The structure and evolution of the western Mediterranean Ridge. Mar Geol 186(1-2):83-110

Reston T, von Huene R, Dickmann T, Klaeschen D, Kopp H (2002b) Frontal accretion along the western Mediterranean Ridge: the effect of Messinian evaporites on wedge mechanics and structural style. Mar Geol 186(1-2):59-82

Robertson A, Kopf A (1998a) Origin of clasts and matrix within the Milano and Napoli mud volcanoes, Mediterranean Ridge accretionary complex. In: Robertson AHF, Emeis K-C, Richter C, Camerlenghi A (eds) Proc ODP, vol 160. Scientific Results (Ocean Drilling Program), College Station, TX, pp 575-595

Robertson A, Kopf A (1998b) Tectonic setting and processes of mud volcanism on the Mediterranean Ridge accretionary complex: evidence from Leg 160. In: Robertson AHF, Emeis K-C, Richter C, Camerlenghi A (eds) Proc ODP, vol 160. Scientific Results (Ocean Drilling Program), College Station, TX, pp 665-680

Robertson A, Shipboard Scientific Party (1996) Mud volcanism on the Mediterranean Ridge: initial results of Ocean Drilling Program Leg 160. Geology 24(3):239-242

Ryan W, Kastens K, Cita M (1982) Geological evidence concerning compressional tectonics in the eastern Mediterranean. Tectonophysics 86(1-3):213-242

Sage F, Von Gronefelda G, Deverchère J, Gaullier V, Maillard A, Gorini C (2005) Seismic evidence for Messinian detrital deposits at the western Sardinia margin, northwestern Mediterranean. Mar Pet Geol 22:757-773

Schulz H, Emeis K, Volkmann N (1997) Organic carbon provenance and maturity in the mud breccia from the Napoli mud volcano: indicators of origin and burial depth. Earth Planet Sci Lett 147(1-4):141-151

Silver E, Breen N, Prasetyo H, Hussong D (1986) Multibeam study of the Flores backarc thrust belt, Indonesia. J Geophys Res B 91(3):3489-3500

Sorel D (2000) A Pleistocene and still-active detachment fault and the origin of the Corinth-Patras rift, Greece. Geology 28(1):83-86

Sorel D, Bizon G, Aliaj S, Hasani L (1992) Stratigraphical data on the age and duration of the compressional tectonic phases in the external Hellenids (NW Greece and Albania) since the Miocene. Bull Soc Geol Fr 163(4):447-454

Staffini F, Spezzaferri S, Aghib F (1993) Mud diapirs of the Mediterranean Ridge; sedimentological and micropaleontological study of the mud breccia. Riv It Paleontol Stratigr 99(2): 225-254

Sumner R, Westbrook G (2001) Mud diapirism in front of the barbados accretionary wedge: the influence of fracture zones and north America-south America plate motions. Mar Pet Geol 18(5):591-613

Van Rensbergen P, Depreiter D, Pannemans B, Moerkerke G, Van Rooij D, Marsset B, Akhmanov G, Blinova V, Ivanov M, Rachidi M, Magalhaes V, Pinheiro M, Cunha M, Henriet JP (2005) The El arraiche mud volcano field at the Moroccan Atlantic slope, Gulf of Cadiz. Mar Geol 219(1):1-17 
Volgin A, Woodside J (1996) Sidescan sonar images of mud volcanoes from the Mediterranean Ridge; possible causes of variations in backscatter intensity. Mar Geol 132(1-4):39-53

Westbrook G, Reston T (2002) The accretionary complex of the Mediterranean Ridge: tectonics, fluid flow and the formation of brine lakes. Mar Geol 186(1-2):1-8

Woodside JM, David L, Frantzis A, Hooker SK (2006) Gouge marks on deep-sea mud volcanoes in the eastern Mediterranean: caused by Cuvier's beaked whales ? Deep Sea Res Part I-Oceanograp Res. Papers 53:1762-1771
Zitter T (2004) Mud volcanism and fluid emissions in Eastern Mediterranean neotectonic zones. Ph.D. thesis, Vrije Universiteit, Amsterdam, $140 \mathrm{pp}$

Zitter TAC, Huguen C, Woodside JM (2005) Geology of mud volcanoes in the eastern Mediterranean from combined sidescan sonar and submersible surveys. Deep Sea Res. Part I-Oceanogr Res Papers 52(3):457-475 